\title{
Enzyme/Nanocopper Hybrid Nanozymes: Modulating Enzyme-like Activity by the Protein Structure for Biosensing and Tumor Catalytic Therapy
}

Noelia Losada-Garcia, Ana Jimenez-Alesanco, Adrian Velazquez-Campoy, Olga Abian, and Jose M. Palomo*

Cite This: ACS Appl. Mater. Interfaces 2021, 13, 5111-5124

Read Online

ABSTRACT: Artificial enzymes with modulated enzyme-mimicking activities of natural systems represent a challenge in catalytic applications. Here, we show the creation of artificial $\mathrm{Cu}$ metalloenzymes based on the generation of $\mathrm{Cu}$ nanoparticles in an enzyme matrix. Different enzymes were used, and the structural differences between the enzymes especially influenced the controlled the size of the nanoparticles and the environment that surrounds them. Herein, we demonstrated that the oxidase-like catalytic activity of these copper nanozymes was rationally modulated by enzyme used as a scaffold, with a special role in the nanoparticle size and their environment. In this sense, these nanocopper hybrids have confirmed the ability to mimic a unique enzymatic activity completely different from the natural activity of the enzyme used as a scaffold, such as tyrosinase-like activity or as Fenton catalyst, which has extremely higher stability than natural mushroom tyrosinase. More interestingly, the oxidoreductase-like activity of nanocopper hybrids was cooperatively modulated with the synergistic effect between the enzyme and the nanoparticles improving the catalase activity (no peroxidase activity). Additionally, a novel dual (metallic and enzymatic activity) of the nanozyme made the highly improved catechol-like activity interesting for the design of 3,4-dihydroxy-Lphenylalanine (L-DOPA) biosensor for detection of tyrosinase. These hybrids also showed cytotoxic activity against different tumor cells, interesting in biocatalytic tumor therapy.

KEYWORDS: nanozymes, copper hybrids, nanoparticles, oxidase-like activity, biosensors, cytotoxicity

\section{INTRODUCTION}

One of the key advantages of enzymes is the high selectivity and activity against a particular reaction; however, outside of cells, they present low activity against non-natural substrate and low stability in different media than biological environment, which are important drawbacks for commercial applications. Also, difficult and time-consuming purification steps, which resulted in a final high cost of the product, limit their industrial application.

Nanozymes have emerged in the last years as one of the most interesting alternatives to natural enzymes, and even conventional enzyme mimics, as artificial biocatalytic tools for decontamination, biosensor, and biomedical applications. ${ }^{1-14}$

At this point, nanozymes show unique advantages over natural enzymes offering robustness to harsh environments, high stability, long-term storage, ease of modification, and lower manufacturing cost than protein enzymes. Additionally, nanozymes possess inherent nanomaterial properties, providing not only a simple substitute of enzymes but also a multimodal platform interfacing complex biologic environments. ${ }^{3,15,16}$
However, one of the most challenging tasks is the development of novel strategies to synthesize nanozymes that mimic a particular natural activity, especially capable of specific enzymatic activity that has not been studied much.

Most of the currently developed nanozymes still face several challenges such as limited specificities and catalytic activities compared with their natural counterparts. ${ }^{17,18}$ To overcome these challenges, several strategies based on the functionalization of nanozymes surface or designing novel nanozymes with structures similar to the active site of natural enzymes have been described. ${ }^{19,20}$

Thus, creating new properties with respect to natural enzymes with improved stability or even finding synergistic processes between enzyme and metallic catalytic centers ${ }^{21-23}$ are challenging.

Received: November 17, 2020

Accepted: January 12, 2021

Published: January 21, 2021 


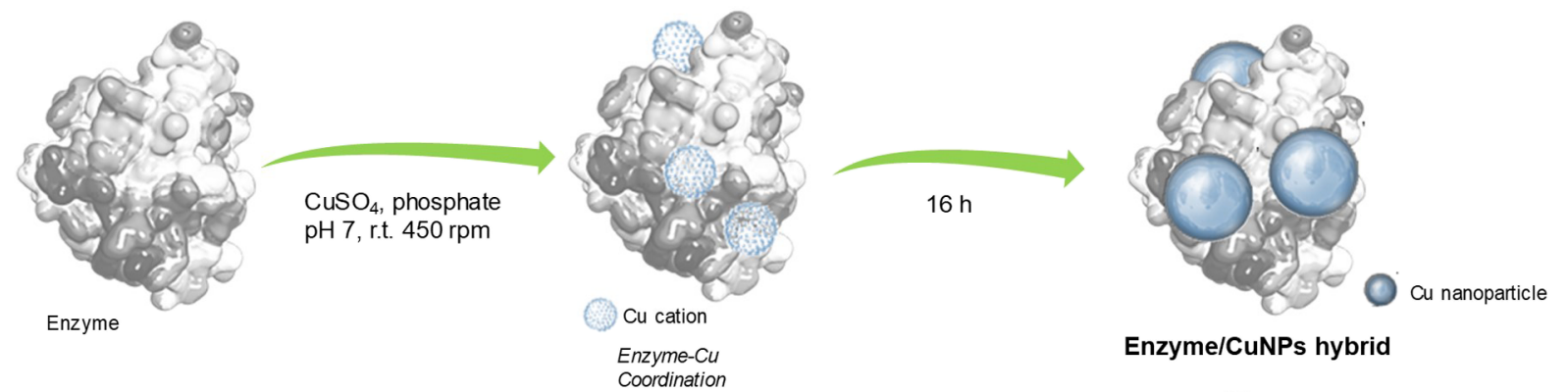

b

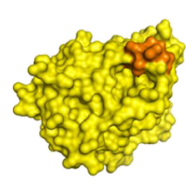

C. antarctica $B$ lipase (CAL-B)

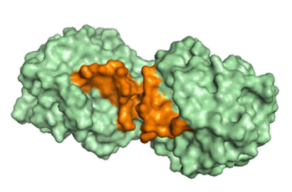

T. Lanuginosus lipase (TLL)

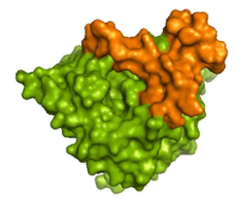

B. Thermocatenulatus lipase (BTL)

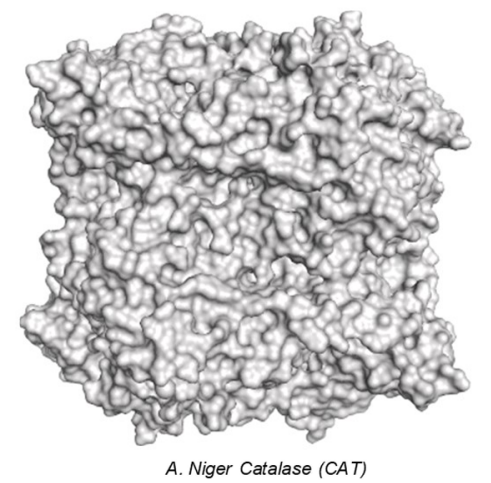

Figure 1. General concept and design of enzyme/CuNP hybrids as novel nanozymes. (a) Synthetic strategy. (b) Different enzymes used as protein scaffolds (the orange color represents the oligopeptide lid in lipases).

In particular, mimics of copper metalloenzymes is an important case, considering the essential biological role of these enzymes. ${ }^{24-28}$ Phenol oxidases (catechol oxidases, tyrosinases (TYR)), catalases, and superoxide dismutase activities are involved in many different cellular process, and deficiency or malfunction of these activities is postulated to be related to the pathogenesis of many age-associated degenerative diseases like diabetes mellitus, hypertension, anemia, vitiligo, Alzheimer's disease, Parkinson's disease, bipolar disorder, cancer, and schizophrenia. ${ }^{29-33}$

In this work, we demonstrate how to modulate the particular enzyme-like activity of novel copper nanohybrids, formed by copper nanoparticles (as active sites) created in a protein environment (as a scaffold), where precisely the used enzyme plays a fundamental role.

Here, we found that depending on the enzyme used in the synthesized hybrid (Figure 1), it was possible to obtain $\mathrm{Cu}$ nanozymes with modulated activity by altering the nanoparticle morphology and reactivity. For that purpose, enzymes with different natures, behaviors, and sizes were tested, with the ability to mimic particular enzyme activity completely different from the natural activity of the enzyme used as a scaffold, the highest tyrosinase-like activity, or even other oxidase activity in Fenton processes, ${ }^{34}$ for catalysis, for example, applied in biocatalytic tumor therapy. ${ }^{35,36}$

Furthermore, a synergistic effect between the enzyme as a scaffold and the CuNPs was observed for an enhanced catalase activity.

\section{EXPERIMENTAL SECTION}

2.1. Chemicals. Lipase B from Candida antarctica (CALB) solution (Lipozyme CALB), lipase from Thermomyces lanuginosus (TLL) solution (Lipozyme TL 100L), catalase from Aspergillus niger (CAT) solution (Catazyme), and glucose oxidase (Gluzyme Mono $10.000 \mathrm{BG}$ ) (GOX) were purchased from Novozymes (Copenhagen, Denmark). Genetically modified lipase from ((Geo)Bacillus thermoca- tenulatus without native cysteines (C65S/C296S) BTL) was produced by Dr. de las Rivas and purified following the previous report (obtaining a solution of $2.5 \mathrm{mg}$ lipase/mL by Bradford assay determination). ${ }^{37}$ Copper(II) sulfate pentahydrate $\left[\mathrm{Cu}_{2} \mathrm{SO}_{4} \cdot 5 \mathrm{H}_{2} \mathrm{O}\right]$ and hydrogen peroxide (33\%) were from Panreac (Barcelona, Spain). $p$-Aminophenol ( $p \mathrm{NP})$, sodium phosphate, sodium acetate, tyrosinase (TYR) from mushroom, 2,2'-azino-bis(3-ethylbenzothiazoline-6sulfonic acid)diammonium salt (ABTS), benzoquinone, and hydroquinone were purchased from Sigma-Aldrich (St. Louis, MO). 3,4Dihydroxy-L-phenylalanine (L-DOPA) was from Alfa-Aesar (MA, EEUU). 3,4-Dihydroxy-L-phenylalanine methyl ester hydrochloride (L-DOPA methyl ester (DOPAME)) was purchased from Carbosynth (Berkshire, U.K.). Horseradish peroxidase (HRP) was from Thermo Scientific (Madrid, Spain).

2.2. Instrumentation. $\mathrm{Cu}$ nanoparticles sizes and morphology were determined by transmission electron microscopy (TEM) and high-resolution TEM (HRTEM). Images were obtained on a $2100 \mathrm{~F}$ microscope (JEOL, Tokyo, Japan) equipped with an energydispersive X-ray (EDX) detector INCA X-sight (Oxford Instruments, Abingdon, U.K.). Interplanar spacing in the nanostructures was calculated using inversed Fourier transform spectroscopy with the GATAN digital micrograph program (Corporate Headquarters, Pleasanton, CA). Scanning electron microscopy (SEM) imaging was performed on a TM-1000 microscope (Hitachi, Tokyo, Japan). Inductively coupled plasma-optical emission spectrometry (ICP-OES) was performed on an OPTIMA $2100 \mathrm{DV}$ instrument (PerkinElmer, Waltham, MA). X-ray diffraction (XRD) patterns were obtained using a Texture Analysis D8 Advance diffractometer (Bruker, Billerica, MA) with $\mathrm{Cu} \mathrm{K} \alpha$ radiation. To recover the nanobiohybrids, a Biocen $22 \mathrm{R}$ (Orto-Alresa, Ajalvir, Spain) refrigerated centrifuge was used. Spectrophotometric analyses were run on a V-730 spectrophotometer (JASCO, Tokyo, Japan). A synergy HT (BioTek) plate reader was used for cell viability assays.

2.3. General Synthesis of Enzyme-Cu(II)NP Hybrids. A corresponding amount of enzyme was added to $60 \mathrm{~mL}$ of sodium phosphate buffer ( $0.1 \mathrm{M}, \mathrm{pH} 7)$ to finally achieve an enzyme concentration of $0.27-0.3 \mathrm{mg} / \mathrm{mL}$. In the case of CALB solution, 1.8 $\mathrm{mL}$ ( $9 \mathrm{mg}$ lipase $/ \mathrm{mL}$ determined by Bradford assay) was added; 0.75 $\mathrm{mL}$ of TLL solution $(24 \mathrm{mg} / \mathrm{mL}$ determined by Bradford assay) and 
$0.5 \mathrm{~mL}$ of CAT $(32 \mathrm{mg} / \mathrm{mL}$ determined by Bradford assay) were added, respectively. In the case of BTL, $20 \mathrm{~mL}(0.4 \mathrm{mg} / \mathrm{mL}$ solution containing $0.5 \%(\mathrm{w} / \mathrm{v})$ of Triton X-100 from the purification step) was added, corresponding to an enzyme concentration of $0.13 \mathrm{mg} /$ $\mathrm{mL}$. The corresponding enzyme solution was poured in a $100 \mathrm{~mL}$ glass bottle containing a small magnetic bar stirrer $\left(12 \times 4.5 \mathrm{~mm}^{2}\right)$. The solution was stirred in a magnetic agitator at $380-450 \mathrm{rpm}$ for 1-2 min. Then, $600 \mathrm{mg}$ of $\mathrm{Cu}_{2} \mathrm{SO}_{4} \cdot 5 \mathrm{H}_{2} \mathrm{O}(10 \mathrm{mg} / \mathrm{mL})$ was added to the protein solution and it was maintained for $16 \mathrm{~h}$ at room temperature (rt). After that, in all cases, the mixture was centrifuged at $8000 \mathrm{rpm}$ for $5 \mathrm{~min}$ (10 $\mathrm{mL}$ per falcon-type tube). The generated pellet was resuspended in $15 \mathrm{~mL}$ of water, washed and centrifuged again at $8000 \mathrm{rpm}$ for $5 \mathrm{~min}$, and the supernatant was removed. The process was repeated twice more. Finally, the supernatant was removed and the pellet of each falcon was resuspended in $2 \mathrm{~mL}$ of water; each solution collected in a cryotube was frozen with liquid nitrogen and lyophilized for $16 \mathrm{~h}$. After that, in all cases, approximately $350 \mathrm{mg}$ of a blue solid was obtained. The different hybrids were called as $\mathrm{Cu}-\mathrm{CALB}, \mathrm{Cu}-\mathrm{TLL}, \mathrm{Cu}-\mathrm{CAT}$, and $\mathrm{Cu}-\mathrm{BTL}$. In the case of CAT, the protocol was repeated avoiding the lyophilization step, conserving the catalyst as a blue liquid suspension. This was called Cu-CAT-NL. Characterization of the different $\mathrm{Cu}$ hybrids was performed by XRD, SEM, TEM, HRTEM, circular dichroism (CD), and fluorescence analysis.

2.4. Circular Dichroism Measurements. Circular dichroism (CD) spectra of the different lipases were recorded in a Chirascan spectropolarimeter (Applied Photophysics) at $25( \pm 1){ }^{\circ} \mathrm{C}$. Far-UV spectra were recorded at wavelengths between 190 and $260 \mathrm{~nm}$ in a $0.1 \mathrm{~cm}$ path-length cuvette. Near-UV spectra were recorded at wavelengths between 250 and $310 \mathrm{~nm}$ in a $1 \mathrm{~cm}$ path-length cuvette. Protein concentrations were 20 and $10 \mu \mathrm{M}$, respectively, in phosphate-buffered saline (PBS), pH 7.2 (bioMerieux).

2.5. Fluorescence Spectroscopy Measurements. Fluorescence measurements were performed in a Varian Cary Eclipse fluorescence spectrophotometer (Agilent Technologies) monitoring the intrinsic tryptophan fluorescence in $2 \mu \mathrm{M}$ of hybrid solutions, using an excitation wavelength of $280 \mathrm{~nm}$, with excitation and emission bandwidths of $5 \mathrm{~nm}$ and recording fluorescence emission spectra between 300 and $400 \mathrm{~nm}$ with $1 \mathrm{~nm}$ step. All spectroscopic measurements were made in water.

2.6. Tyrosinase-like Activity Assay. 3,4-Dihydroxy-L-phenylalanine (L-DOPA) $(4 \mathrm{mg}, 1 \mathrm{mM})$ or L-DOPA methyl ester $(5 \mathrm{mg}, 1$ $\mathrm{mM}$ ) was added to a $20 \mathrm{~mL}$ water solution, $0.1 \mathrm{M}$ buffer sodium phosphate $(\mathrm{pH} 7)$, or $0.1 \mathrm{M}$ buffer sodium acetate $(\mathrm{pH} 4)$. To initialize the reaction, $5 \mathrm{mg}$ of $\mathrm{Cu}$-enzyme hybrid or $50 \mu \mathrm{L}$ of commercial mushroom tyrosinase (TYR) $(1 \mathrm{mg} / \mathrm{mL}$ solution in distilled water) was added to $2 \mathrm{~mL}$ of DOPA solution and the mixture was slight stirred (roller) at room temperature. In the case of solid $\mathrm{Cu}$ hybrids, at different times, the mixture was centrifuged at $3000 \mathrm{rpm}$ for $1 \mathrm{~min}$ and the absorbance of the supernatant (at different times) was measured at $475 \mathrm{~nm}$ in a JASCO V-730 UV spectrophotometer. Then, the Abs/min was calculated with these values in each case. In the case of tyrosinase, the increase of absorbance was directly measured at $475 \mathrm{~nm}$ with a UV spectrophotometer using the kinetic program. An enzyme activity unit (U) was defined as the amount of enzyme causing an increase of absorbance by $0.001 / \mathrm{min}$ at $25^{\circ} \mathrm{C} .{ }^{38}$ Experiments were also conducted in the presence of different concentrations of $\mathrm{H}_{2} \mathrm{O}_{2}(0-50 \mathrm{mM})$.

2.7. Catalase-like Activity Assay. Hydrogen peroxide $\left(\mathrm{H}_{2} \mathrm{O}_{2}\right)$ $(33 \%(\mathrm{w} / \mathrm{w}))$ solution in distilled water was prepared to obtain a final concentration of $50 \mathrm{mM}$. The solution $\mathrm{pH}$ was adjusted to 7 using $\mathrm{NaOH}$. To start the reaction, $2 \mathrm{mg}$ of the Cu hybrid or $100 \mu \mathrm{L}$ of Catazyme $25 \mathrm{~L}(31 \mathrm{mg} / \mathrm{mL})$ was added to 2 or $10 \mathrm{~mL}$ of the $50 \mathrm{mM}$ solution at room temperature, respectively. The reaction was followed by measuring the degradation of hydrogen peroxide recording the decrease of absorbance spectrophotometrically at $240 \mathrm{~nm}$ in quartz cuvettes of $1 \mathrm{~cm}$ path length, at different times. To determine the catalase activity for each catalyst, the $\Delta \mathrm{Abs} / \mathrm{min}$ value was calculated using the linear portion of the curve $\left(\Delta \mathrm{Abs}_{\mathrm{S}}\right)$.
The specific activity $(\mathrm{U} / \mathrm{mg})$ was calculated using the following equation

$$
U\left(\mu \mathrm{mol} /(\operatorname{min~} \mathrm{mg})=\Delta \mathrm{Abs} / \mathrm{min} \cdot V \cdot \frac{1000}{\varepsilon \cdot \mathrm{mg}_{\text {catalyst }}}\right.
$$

where the molar extinction coefficient $(\varepsilon)$ used was $43.6 \mathrm{M}^{-1} \mathrm{~cm}^{-1}$ and $\mathrm{mg}$ of enzyme or $\mathrm{Cu}$ content was used.

2.8. Fenton Catalyst Assay. $p$-Aminophenol ( $p$ AP) ( $1 \mathrm{mg}$ ) was dissolved in solutions $(10 \mathrm{~mL})$ of distilled water, and $100 \mathrm{mM}$ hydrogen peroxide $(1 \%, \mathrm{v} / \mathrm{v})$ was added. To initialize the reaction, 10 $\mathrm{mL}$ of this solution was added to a glass bottle containing $3 \mathrm{mg}$ of $\mathrm{Cu}$ hybrid and stirred gently at room temperature on an orbital shaker $(320 \mathrm{rpm})$. At different times, samples $(100 \mu \mathrm{L})$ were taken and the reaction was followed by high-performance liquid chromatography (HPLC). The samples were first centrifuged at $8000 \mathrm{rpm}$ for $5 \mathrm{~min}$ and then $50 \mu \mathrm{L}$ was diluted 20 times in bidistilled water before injection. HPLC column was C8 kromasil $150 \times 4.6 \mathrm{~mm}^{2}$ AV-2059. HPLC conditions were: an isocratic mixture of $15 \%$ acetonitrile and $85 \%$ bidistilled water, UV detection at $270 \mathrm{~nm}$, and a flow rate of 0.4 $\mathrm{mL} / \mathrm{min}$. Under these conditions, retention times of $p \mathrm{AP}$ and $\mathrm{H}_{2} \mathrm{O}_{2}$ were 8.5 and $4.2 \mathrm{~min}$, respectively. The possible adsorption of substrate to the catalyst was first tested, and without the presence of hydrogen peroxide, no reaction was observed and the full area of the substrate was unaltered in the HPLC analysis.

In the case of Cu-CALB, the reaction was repeated in the presence of $0.1 \mathrm{mmol}$ (2,2,6,6-tetramethylpiperidin-1-yl)oxyl (TEMPO) (48 $\mathrm{mg}$ of polymer-bound TEMPO).

2.9. Stabilization of the $\mathrm{Cu}$ Nanozymes. The stability of different enzyme/CuNP hybrids was evaluated by incubating them for $1 \mathrm{~h}$ at different temperatures in the presence of co-solvent or additives ( $1 \mathrm{mM}$ of known tyrosinase inhibitors). Then, the tyrosinase-like activity of hybrids and enzymatic activity of tyrosinase (TYR) from mushroom was used for monitoring the stability, considering the activity at $25^{\circ} \mathrm{C}$ in each case as $100 \%$. The activity was determined using the DOPA assay described above. In the case of the presence of tyrosinase inhibitors, the activity evaluation was performed at $25^{\circ} \mathrm{C}$ in aqueous media.

2.10. Cell Cultures. HT29 (human colon adenocarcinoma) and HeLa (human cervix epithelioid carcinoma) cells were obtained from ATCC and maintained in Dulbecco's modified Eagle's medium (DMEM) (PAN-Biotech GmbH, Germany) supplemented with 10\% fetal bovine serum (FBS), 1\% penicillin/streptomycin (P/S), and $1 \%$ non-essential amino acids (NEAAs) at $37^{\circ} \mathrm{C}$ with $5 \% \mathrm{CO}_{2}$.

2.11. Cell Viability Assays. Cellular cytotoxicity was assessed in two cell lines: HT29 and HeLa cells. Cells were plated in 96-well plates (8000 cells $/ 90 \mu \mathrm{L} /$ well in HeLa cells; 9000 cells $/ 90 \mu \mathrm{L} /$ well in HT29 cells) with supplemented DMEM without phenol red. After 24 h, $10 \mu \mathrm{L}$ of several serial dilutions of the compounds was added to the cells (the solutions were prepared at $10 \times$ and the maximum concentration of compounds added to cells was the one in which there were $5 \%$ of $\mathrm{H}_{2} \mathrm{O}$ in each solution). The cells were in presence of the compounds during $24 \mathrm{~h}$, and after this period, the cytotoxicity was checked by a 3-(4,5-dimethylthiazol-2-yl)-2,5-diphenyl tetrazolium bromide (MTT)-based assay. 3-(4,5-Dimethylthiazol-2-yl)-2,5-diphenyl tetrazolium bromide (MTT) reagent (Sigma Corp., St. Louis, MO) was prepared by dissolving $5 \mathrm{mg}$ in $1 \mathrm{~mL}$ of PBS. The stock solution was protected from light and stored at $4{ }^{\circ} \mathrm{C}$. To determine cytotoxicity, media was removed from wells and $50 \mu \mathrm{L}$ of the working MTT solution ( $1 \mathrm{mg} / \mathrm{mL}$ in DMEM without phenol red) was added to each well and incubated at $37^{\circ} \mathrm{C}$ for $3 \mathrm{~h}$ in a humidified, $5 \% \mathrm{CO}_{2}$ atmosphere. After that, the media was carefully removed and the cells were solubilized into $100 \mu \mathrm{L}$ of isopropanol (Scharlab, S.L., Barcelona, Spain). After $15 \mathrm{~min}$ shaking cautiously and protecting from light, the absorbance was recorded at $570 \mathrm{~nm}$ (reference wavelength: $650 \mathrm{~nm}$ ) using a Synergy HT (BioTek) plate reader. Each experiment was performed in quadruplicate, repeated at least two times, and normalized regarding untreated cell viability. 
I

a

b
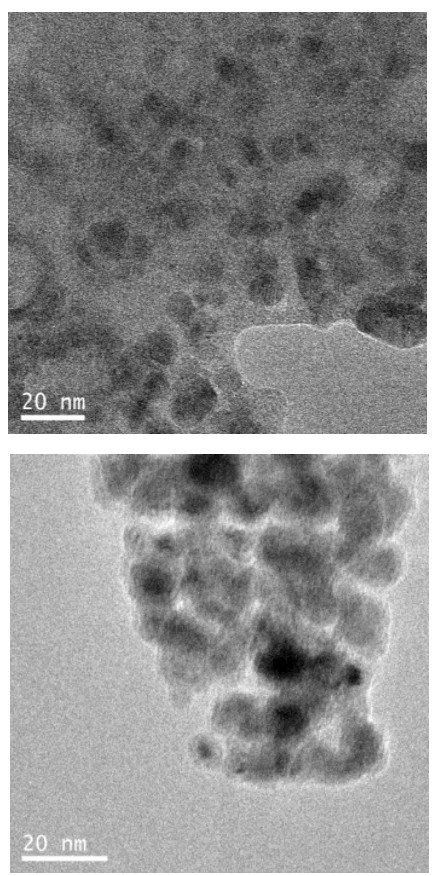

C

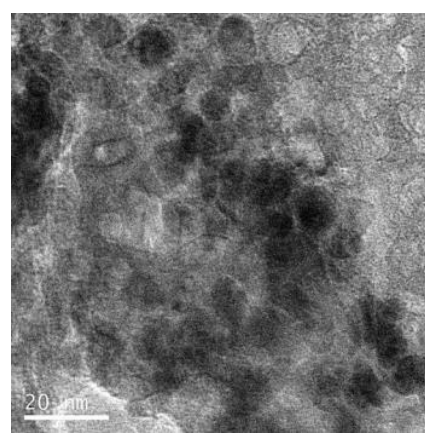

d

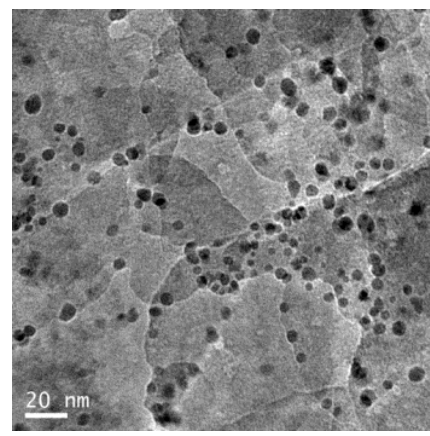

II
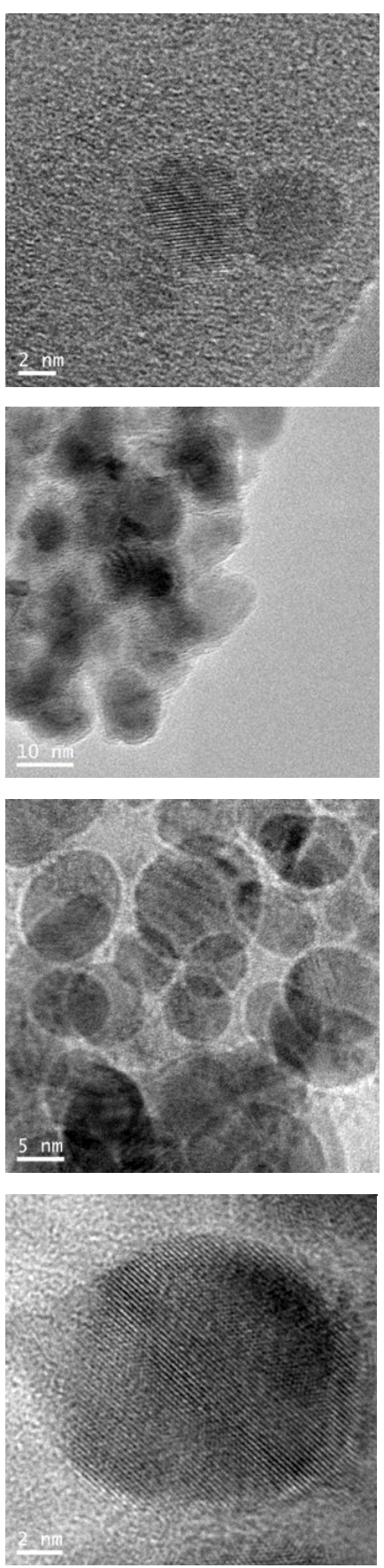

III
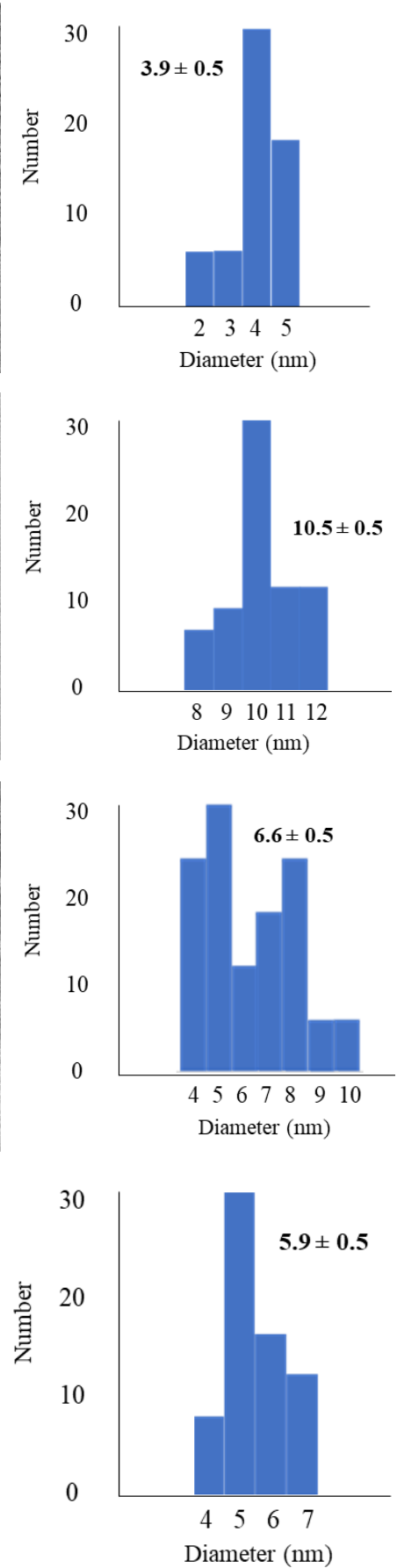

Figure 2. Characterization of different enzyme/CuNP hybrids: (a) Cu-CALB, (b) Cu-TLL, (c) Cu-BTL, and (d) Cu-CAT. (I) Transmission electronic microscopy (TEM) images; (II) high-resolution (HR)-TEM images; and (III) nanoparticle size distribution.

\section{RESULTS AND DISCUSSION}

\subsection{Synthesis and Characterization of Enzyme/CuNP}

Hybrids. The preparation of copper nanoparticle hybrids as novel nanozymes was attempted. Here, different enzymeswhich involved different conformational structures, dimeric or multimeric complexes, or even introducing post-translational modifications-were used in the preparation of enzyme/CuNP hybrids. In all cases, protein amounts of $0.27-0.3 \mathrm{mg} / \mathrm{mL}$ dissolved in phosphate buffer $\mathrm{pH} 7$ were incubated with
$\mathrm{CuSO}_{4}(10 \mathrm{mg} / \mathrm{mL})$ for $16 \mathrm{~h}$. A solid obtained after centrifugation indicates the final process of the $\mathrm{Cu}$ hybrid synthesis. The strategy was performed directly in aqueous solution at room temperature using the following enzymes: three different lipases, lipase from C. antarctica B (CALB) (33 $\mathrm{kDa}$ ), lipase from (G.)B. thermocatenulatus (BTL) (43 kDa) and lipase from T. lanuginosus (TLL) (33 kDa, dimer), and a catalase produced by a genetically modified strain of the fungus A. niger (CAT) ( $80 \mathrm{kDa}$, tetramer). 
a

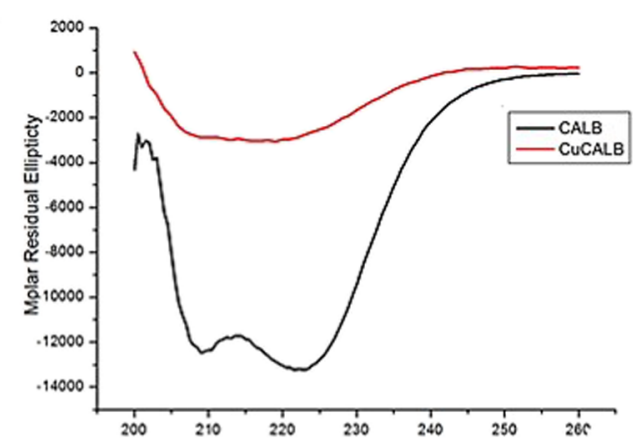

c

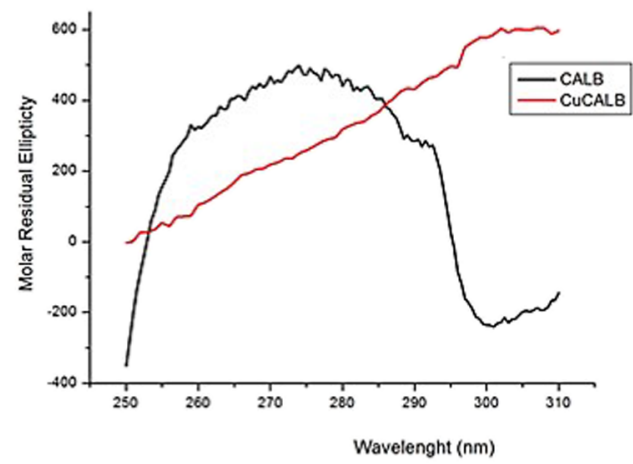

e

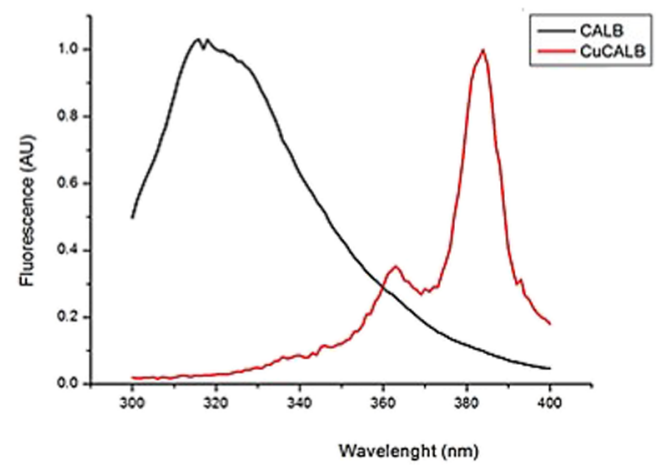

b
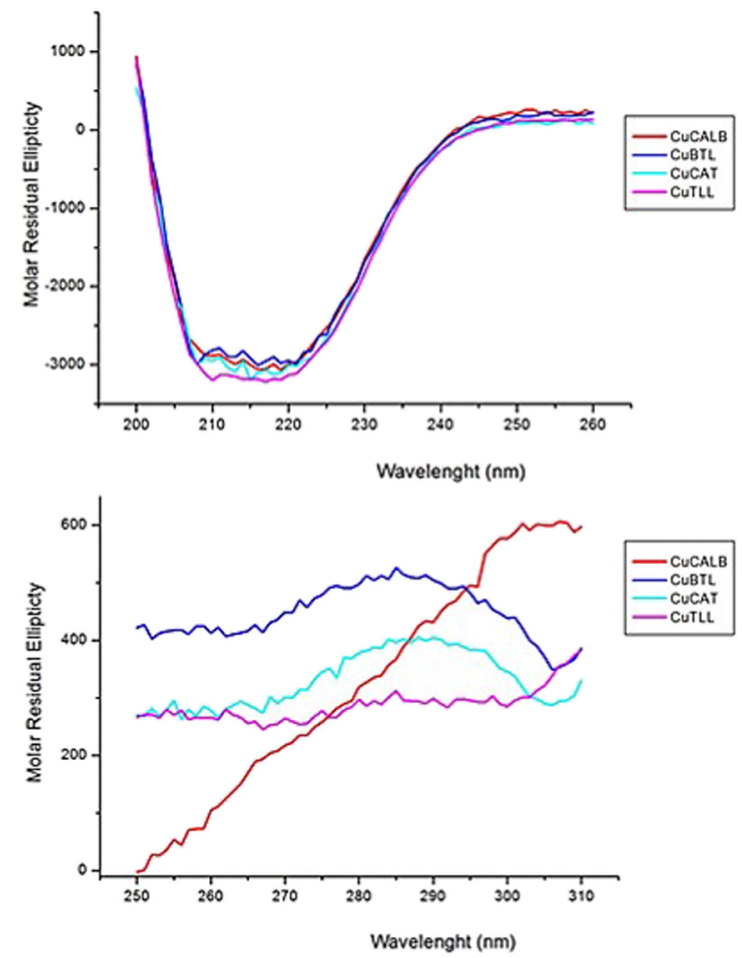

$\mathbf{f}$

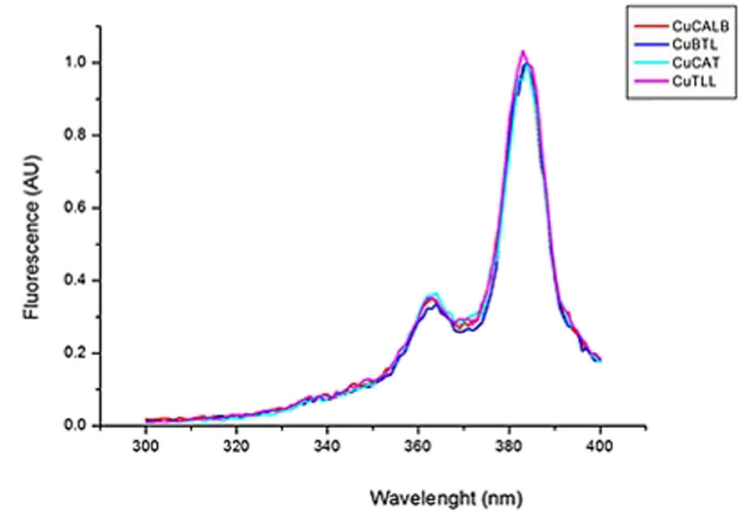

Figure 3. Spectroscopy characterization (CD and fluorescence) of the different enzyme/CuNP hybrids. (a) Far-CD spectra of Cu-CALB hybrid compared to soluble CALB. (b) Far-CD spectra of the different Cu hybrids. (c) Near-CD spectra of Cu-CALB hybrid compared to soluble CALB. (d) Near-CD spectra of the different Cu hybrids. (e) Fluorescence spectra of Cu-CALB hybrid compared to soluble CALB. (f) Fluorescence spectra of the different $\mathrm{Cu}$ hybrids. Fluorescence measurements were performed using an excitation wavelength of $280 \mathrm{~nm}$, with excitation and emission bandwidths of $5 \mathrm{~nm}$.

The final step in obtaining enzyme/CuNP hybrids involved the lyophilization of a frozen suspension of the solid. At this term, we could obtain at multimilligram scale a set of different $\mathrm{Cu}$ hybrids called as $\mathrm{Cu}-\mathrm{CALB}, \mathrm{Cu}-\mathrm{TLL}, \mathrm{Cu}-\mathbf{B T L}$, or $\mathbf{C u}-$ CAT.

Wide-angle X-ray diffraction (XRD) analyses revealed a similar XRD pattern for all of enzyme/CuNP hybrids, displaying characteristic peaks of $\mathrm{Cu}_{3}\left(\mathrm{PO}_{4}\right)_{2}$ (matched well with JCPDS card no. 00-022-0548 and some reports ${ }^{39,40}$ ) as unique copper species (Figure S1). Transmission electronic microscopy (TEM) revealed the formation of small-size crystalline nanoparticles on the protein network in the $\mathrm{Cu}$ hybrids (Figures 2 and S2-S5). However, the homogeneous nanoparticles distribution and especially the nanoparticles size were different depending on the enzyme used as a scaffold. $\mathrm{Cu}$ (II) nanoparticles around 3-10 nm were generated, and we could see in some cases their size increased with the size of the protein. Larger nanoparticles were obtained with TLL $(10 \mathrm{~nm})$ (Figure 2b). The explanation of the size and the less homogeneity of the nanoparticles with this enzyme could be because of the extremely high capacity of this enzyme to aggregation, ${ }^{41}$ which has been crystallized in tetrameric or even octameric form; therefore, we can consider this case a real enzyme unit as more than $100 \mathrm{kDa}$. Comparing CALB to CAT, we can clearly see that the size of nanoparticles increased from 3.9 (for CALB, Figure 2a) to around $6 \mathrm{~nm}$ because of the protein size (Figure 2).

Thus, in the case of BTL, although it is a slightly larger protein than CALB, $\mathrm{Cu}(\mathrm{II})$ nanoparticles of $6.6 \mathrm{~nm}$ were obtained (Figure 2c).

ICP-OES analysis showed that the copper content in the different hybrids was quite similar (34-37\%), with the exception of TLL with a Cu content of $44 \%$ (Table S1). 
a
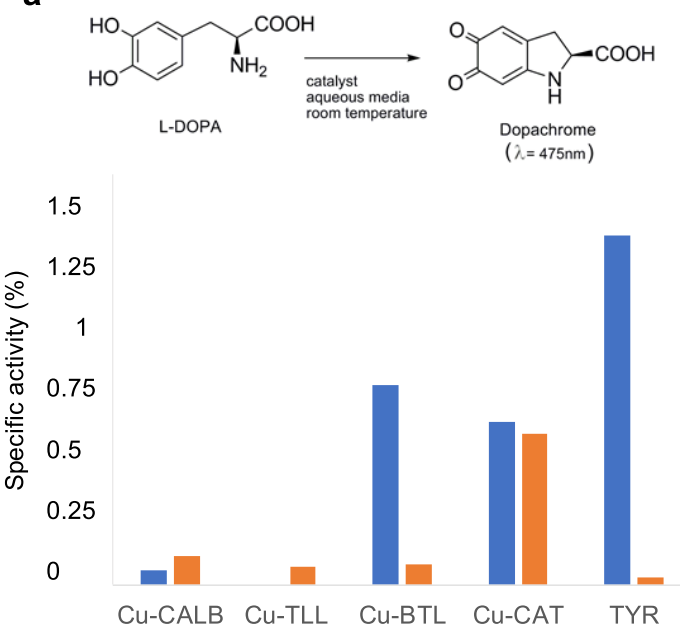

b
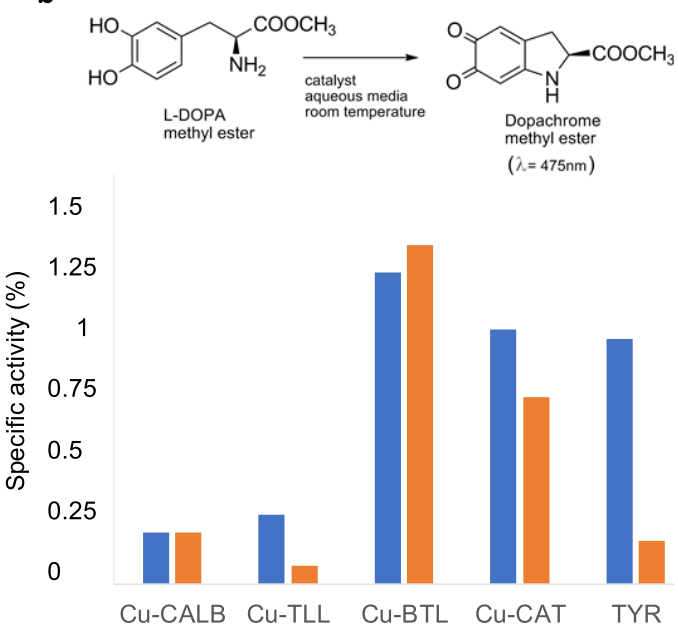

Figure 4. Tyrosinase-like activity of different enzyme/CuNP hybrids. (a) Oxidation of L-DOPA at different conditions expressed in values of specific activity $\left(\mathrm{U} / \mathrm{mg}_{\mathrm{cu}}\right.$ for hybrids or $\mathrm{mg}_{\text {prot }}$ for TYR). (b) Oxidation of L-DOPA methyl ester at different conditions expressed in values of specific activity (U/mg). Distilled water (blue column), $\mathrm{pH} 4$ (orange column). The activity value of TYR is $\times 10^{2}$.

3.2. Spectroscopic Characterization of the Enzyme/ CuNP Hybrids. Far-circular dichroism (CD) for studying the effect of the modification on the secondary structure of enzymes, as well as near-CD and fluorescence assays were performed for analyzing the effect on the tertiary structure (Figure 3). The far-CD spectrum signal obtained was lower in Cu-CALB hybrids in comparison to soluble CALB, but there was still some residual $\alpha$ helix secondary structure (according to the peaks at 208 and $222 \mathrm{~nm}$ ) (Figure 3a). The same behavior was found for the rest of enzyme/CuNP hybrids (Figure $3 \mathrm{~b}$ ). The shape and amount of residual signal were similar in all $\mathrm{Cu}$ hybrids.

CALB near-CD spectrum signal was low, and in case of enzyme/CuNP hybrids, it was lower (or even negligible in some cases) (Figure $3 \mathrm{c}, \mathrm{d}$ ) which means that the tertiary structure was altered upon $\mathrm{Cu}$-enzyme derivative formation.

The fluorescence of protein tryptophan's emission at 345 $\mathrm{nm}$ (upon $275 \mathrm{~nm}$ excitation) has been demonstrated to be quenched by copper and shifted to higher wavelengths (around $400 \mathrm{~nm}){ }^{42}$ A similar behavior was found in these enzyme/ CuNP hybrids. Tryptophan fluorescence signal of CALBsoluble enzyme exhibited a peak at $320 \mathrm{~nm}$ (upon $280 \mathrm{~nm}$ excitation), which was not present in Cu-CALB hybrids (Figure 3e) neither in the rest of enzyme/CuNP hybrids (Figure 3f). However, we observed a clear signal at $385 \mathrm{~nm}$ in the fluorescence spectra of all six Cu hybrids (Figure 3f), which is characteristic of a $\mathrm{Cu}^{2+}$-enzyme complex formation. ${ }^{43}$

3.3. Tyrosinase-Mimicking Activity of Different Enzyme/CuNP Hybrids. Copper tyrosinases (Tyr) represent a very important class of oxidases with a key role in catalytic biological systems. $^{26,27}$ However, high difficulty to obtain highly stable proteins with a high level of expression makes them an excellent example of enzyme type where artificial metalloenzyme can be a challenge. These enzymes can catalyze: (i) the o-hydroxylation of monophenols to $o$ diphenols as well as (ii) the oxidation of $o$-diphenols to produce $o$-quinones. In contrast, and by definition, catechol oxidase can only catalyze the oxidation of $o$-diphenols to their corresponding $o$-quinones. Here, catechol oxidase-like activity of the different enzyme/CuNP hybrids was evaluated using L3,4-dihydroxyphenylalanine (DOPA) and its derivative L-
DOPA methyl ester (DOPAME) as a substrate. Both of these compounds do not absorb in the visible region; however, the oxidation produces a chromogenic product (dopachrome), which is brown in color and absorbs at $475 \mathrm{~nm}$ (Figure 4).

In distilled water and using DOPA as substrate, Cu-BTL showed the highest catechol oxidase activity, almost $1 \mathrm{U} / \mathrm{mg}$, between all of the enzyme/Cu hybrids (Figure $4 \mathrm{a}$ ). However, using the other two $\mathrm{Cu}$ hybrids synthesized using lipases, little (Cu-CALB) or even no catechol-like activity (Cu-TLL) was observed.

However, the evaluation of the activity under acidic conditions ( $\mathrm{pH} 4$ ) shows a significant difference, especially for the hybrid synthesized using BTL, which exhibited 10 times less catechol-like activity, being at these conditions quite similar for all of the lipases. This result was also detected when the catechol activity of mushroom from Agaricus bisporus tyrosinase (TYR) was evaluated. This is a well-known enzyme that is normally used as a model of the human tyrosinase because both have a very high structural homology. ${ }^{44}$

However, when catalase was used as an enzyme for $\mathrm{Cu}$ hybrid formation, the Cu-CAT hybrid showed only a slightly lower activity than $\mathrm{Cu}-\mathrm{BTL}$ at $\mathrm{pH}$ around 6-7, although it was stable to $\mathrm{pH}$ change, with hardly any variation in activity, being the most active $\mathrm{Cu}$ hybrid (more than 5 times than all others) at $\mathrm{pH} 4$ (Figure $4 \mathrm{a}$ ). This is interesting because under these conditions, the catechol activity of this Cu-CAT hybrid is only slightly lower than that of natural TYR (which showed a specific activity of $3 \mathrm{U} / \mathrm{mg}$ ) (Figure $4 \mathrm{a}$ and Table S2).

In all hybrids, the catechol-like activity is provided exclusively by the CuNPs synthesized in the hybrids, and no catechol activity was found with enzymes used as a scaffold (Table S2).

The catechol-like activity of the Cu hybrids using DOPAME as a substrate demonstrated the important effect of blocking the negative charge of the carboxylic group in the substrate. In almost all cases, the activity of the hybrids increased using DOPAME with respect to the activity against DOPA. However, TYR showed a decrease (almost 2-fold in distilled water) in the enzymatic activity when the DOPA derivative was used (Figure $4 \mathrm{~b}$ and Table S3). As occurred with L-DOPA, 
the different enzymes used in the synthesis of $\mathrm{Cu}$ hybrid did not show activity against DOPAME (Table S3).

In distilled water as a solvent, the Cu-BTL hybrid showed the highest activity between all hybrids (Figure 4b). Cu-TLL was active against DOPAME $(0.275 \mathrm{U} / \mathrm{mg})$, in similar values to $\mathrm{Cu}-\mathrm{CALB}$.

The effect of $\mathrm{pH}$ concerning the structure of the protein on activity was clearly shown when the hybrid activity was evaluated at $\mathrm{pH} 4$ (Figure 4b). Using DOPAME, Cu-BTL and Cu-CALB hybrids maintained the same catechol activity as distilled water, although the decrease in the activity value was found for $\mathrm{Cu}$-TLL, in which clearly, the $\mathrm{pH}$ conditions are more critical for the $\mathrm{Cu}$-site environment. TYR showed around 5 times higher activity under acidic conditions (Figure 4b) against this substrate compared to DOPA (Figure 4a).

These results could be explained considering the size of the nanoparticles, for example, the synthesis using BTL or CAT as enzymes produced hybrids containing smaller CuNPs than TLL.

Nevertheless, the structural microenvironment created by the particular enzyme, by coordination with copper and amino acid surrounding area, is a key parameter affecting the activity of $\mathrm{Cu}$ active sites. Indeed, the isoelectric point ( $\mathrm{pI}$ ) of the enzyme used as a scaffold had also an important influence on the final catalytic capacity of the $\mathrm{Cu}$ sites independently of the nanoparticle size in each case. In this way, a higher catechol activity could be detected in DOPA assay when the enzyme used as a scaffold showed a higher $\mathrm{pI}$ and enzymes present a $\mathrm{pI}$ of 7.2 for BTL, 6.8 for CAT, 6.0 for CALB, and 4.4 for TLL (Figure 4). In this term, at acidic $\mathrm{pH}$, hybrid synthesized using BTL showed the strongest effect on the activity, whereas $\mathrm{Cu}$ hybrids created using CALB or TLL even suffered an increase of efficiency compared to the former conditions. When the substrate presented the carboxylic group blocked (DOPAME), only slight changes were observed in almost all hybrids, being the best BTL. Considering the $\mathrm{pH}$ effect, in the case of $\mathbf{C u}$ CALB hybrid, an 8 times increase of the catechol activity was observed when the DOPAME reaction was performed at $\mathrm{pH} 7$ (Figure S6).

All of these results demonstrated the key role of the protein environment on the final $\mathrm{Cu}$ activity.

3.4. Catalase-like Activity. Catalase enzyme is essential for the elimination of the excess of cytoplasmic hydrogen peroxides by converting them to water and molecular oxygen. However, most of the activity described in the literature for other $\mathrm{Cu}$ hybrid materials is peroxidase-like activity. ${ }^{45}$

Initially, we tested the peroxidase-like activity of these $\mathrm{Cu}$ hybrids using the glucose assay and no activity was found for these $\mathrm{Cu}$ hybrids (Figure S7). However, the $\mathrm{Cu}$ hybrids degraded the hydrogen peroxide to oxygen in distilled water at room temperature (Figure 5). The $\mathrm{Cu}$ hybrids prepared using lipases showed similar specific activities, slightly higher for $\mathbf{C u}$ BTL $(2.48 \mathrm{U} / \mathrm{mg})$.

However, the degradation of hydrogen peroxide is the natural catalytic reaction of catalase, which under these conditions showed a specific activity of $13 \mathrm{U} / \mathrm{mg}$. Thus, the preparation of a $\mathrm{Cu}$ hybrid using this enzyme as a scaffold could allow us to synthesize a nanozyme with a double activity, a synergy between natural and metallic ones.

However, the Cu-CAT hybrid showed only a slightly better activity than the previous hybrids, around $3.38 \mathrm{U} / \mathrm{mg}$, which corresponds to around $25 \%$ of initial catalase activity of the soluble native enzyme (Figure 5).

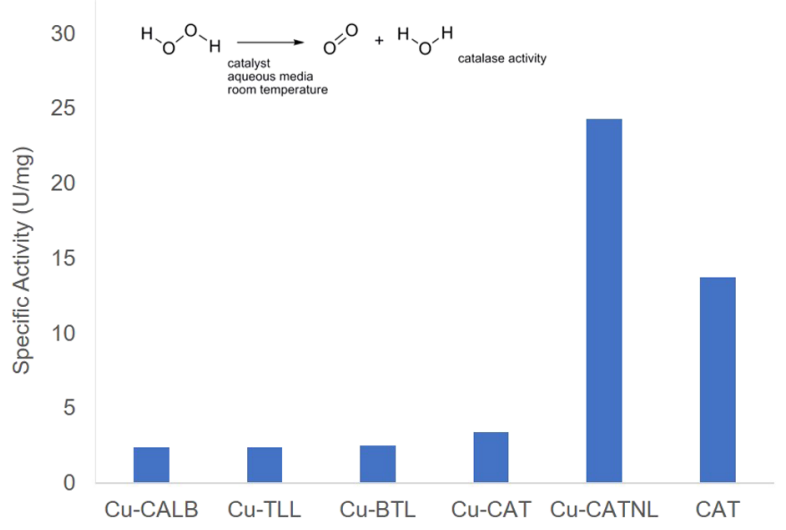

Figure 5. Catalase-like activity of different Enzyme/CuNP hybrids.

One of the explanations could be that it is demonstrated that catalase lost more than $80 \%$ activity after lyophilization, ${ }^{46}$ the last step in the preparation of this hybrid.

Therefore, to overcome this drawback, synthesis of the $\mathrm{Cu}$ hybrid using catalase as an enzyme scaffold was performed following the previous protocol without the lyophilization step, followed by simple washing and storing the solid resuspended in distilled water.

The characterization of this hybrid without freezing (Figure S8) showed that $\mathrm{Cu}$ species were conserved as copper phosphate (XRD analysis), with the formation of homogeneous spherical nanoparticles of diameter $8 \mathrm{~nm}$ (TEM analysis), slightly larger than those generated with the freezing step (Figure 2). ICP-OES analysis determined that the amount of copper was also the same.

This Cu-CAT-NL hybrid showed much better catalase activity, 8 times higher than that of the lyophilized version (Cu-CAT), showing a clear synergy between enzyme and CuNPs in catalyse activity, with double activity compared to free CAT.

The maintenance of the enzyme structure seems to be again important for the CuNPs in addition to the direct intrinsic enzymatic activity.

3.5. Dual Activity of Enzyme/CuNP Hybrids. Studies have demonstrated that the presence of oxygen in the media enhanced the catalytic efficiency of tyrosinase or catecholase in the DOPA reaction.

Considering the previous results of $\mathrm{Cu}-\mathrm{CAT}-\mathrm{NL}$ in catalase activity in the production of free oxygen in solution from hydrogen peroxide, and their catecholase activity against LDOPA, slightly lower than the observed for Cu-CAT, a tandem system combining L-DOPA and hydrogen peroxide, where oxygen in situ could be reacted with the natural enzyme (catalase) for enhancement of the catechol activity of the CuNP sites, was evaluated (Figure 6).

Thus, the Cu-CAT-NL hybrid was used as catalyst in the oxidation of L-DOPA in the presence of different concentrations of hydrogen peroxide (Figure 6).

The results showed how effectively the catecholase activity of the biohybrid increased importantly, up to 6 times, when there was hydrogen peroxide $(50 \mathrm{mM})$ in the medium, due to the synergistic reaction with catalase (enzyme-like scaffold), which increases the presence of oxygen in the medium by degradation of hydrogen peroxide. Lower amounts of hydrogen peroxide also improved the catechol activity of the hybrid Figure 6), but to a lesser extent, showing how the cascade 

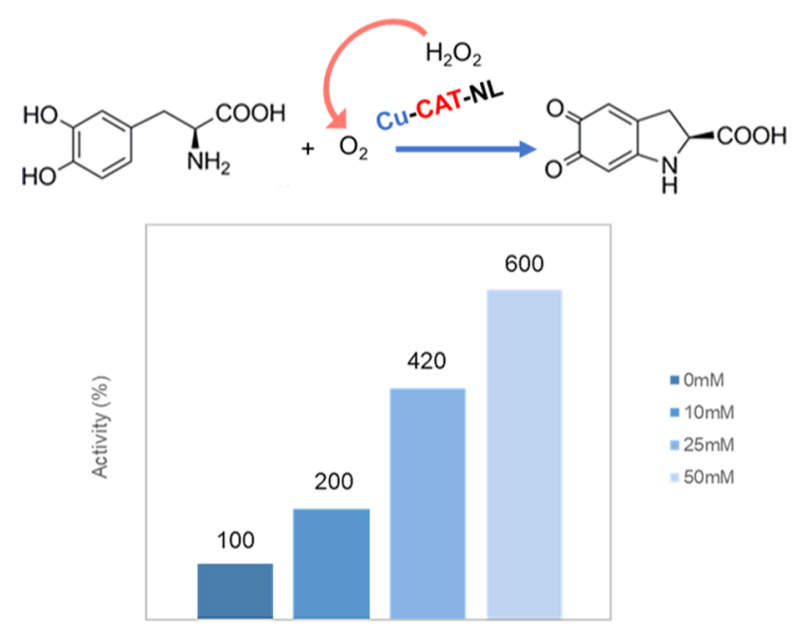

$\left[\mathrm{H}_{2} \mathrm{O}_{2}\right]$

Figure 6. Synergy effect (enzyme plus metal) in the catechol-like activity of Cu-CAT-NL. The specific activity of this hybrid in the absence of hydrogen peroxide was considered as $100 \%$ activity percentage.

system gave rise to an increase in the initially impaired enzymatic activity due to a combined effect of enzymatic and metallic activities of the biohybrid.

3.6. Fenton Catalyst. After these excellent results in modulating tyrosinase and catalase activity, we try to evaluate the effect of the enzyme structure on the Fenton catalysis of the different hybrids.

The selective hydroxylation of $p$-aminophenol to benzoquinone using hydrogen peroxide as a green oxidant was used (Figure 7). The Fenton process was observed with these $\mathrm{Cu}$ hybrids. A clear tendency was observed in the case of using lipases as an enzyme scaffold, where higher conversion is achieved for smaller $\mathrm{Cu}$ nanoparticles. However, the best result was found using CAT as an enzyme, with almost $90 \%$ conversion in $7 \mathrm{~min}$, which indicates the influence of the enzyme structure together with the nanoparticle size.

Furthermore, to demonstrate the Fenton process mechanism of the reaction, with radical $\mathrm{OH}^{\bullet}$ formation, the reaction was also performed in the presence of TEMPO using Cu-CALB as a catalyst (Figure $7 \mathrm{~b}$ ). Under these conditions, only $3 \%$ conversion was observed after $7 \mathrm{~min}$ (60\% without adding TEMPO) with a clear decrease in the reaction process in the reaction profile.

3.7. Assessing Cell Metabolic Activity of the Enzyme/ CuNP Hybrids on Cancer Cells. One of the emerging applications of nanozymes focuses on their in vitro nanocatalytic therapeutic efficiency.

In this term, in vitro cytotoxic activity of the $\mathrm{Cu}$ hybrids has been evaluated in two different cancer cell lines, HeLa (human cervical cancer) and HT29 (human colon cancer cells). Different concentrations of the $\mathrm{Cu}$ hybrids were used in the assay after $24 \mathrm{~h}$ incubation. The cell metabolic activity was determined using the colorimetric 3-(4,5-dimethylthiazol-2yl)-2,5- diphenyl tetrazolium bromide or methyl thiazole tetrazolium bromide (MTT) assay (Figure 8).

The essence of this assay is based on the metabolic reduction of (MTT), which is carried out by the enzyme mitochondrial succinate dehydrogenase from metabolically active mitochondria cells. This enzyme transforms MTT from a yellow hydrophilic soluble compound to a blue hydrophobic insoluble compound (formazan) (Figure 8) by cleavage of the tetrazolium ring by dehydrogenase enzymes. Consequently, this transformation enables the mitochondrial function of the treated cells to be determined. The product of the reaction, formazan, is retained in the cells and can be released by the solution thereof. The ability of the cells to reduce MTT is an indicator of the integrity of mitochondria.

The viability according to $\mathrm{Cu}$ content in hybrids is represented in Figure 9. Differences in cell viability depending on the $\mathrm{Cu}$ hybrids used, as well as different effect depending on the cancer cell lines, can be found, showing higher cytotoxicity against HeLa cells (Figure 9). Cu-CALB and Cu-TLL showed the best cytotoxicity at a lower concentration (0.1 lower concentrations).

The concentration of copper in which $50 \%$ of initial activity is reached (LC50) (Table 1) was determined from the fitting of these curves in Figure 9.

HeLa cells seemed to be more sensitive to $\mathrm{Cu}$ than HT29 cells, up to 10 times in the case of Cu-BTL hybrid ( 0.13 and $1.05 \mu \mathrm{M}$ of $\mathrm{Cu}$, respectively), which showed the lowest LC50 values in HeLa cells (Table 1). In the case of Cu-CAL-B, this showed the lowest LC50 values $(0.37 \mu \mathrm{M}$ of $\mathrm{Cu})$ in HT29 cell lines also being one of the best in cytotoxicity against HeLa a

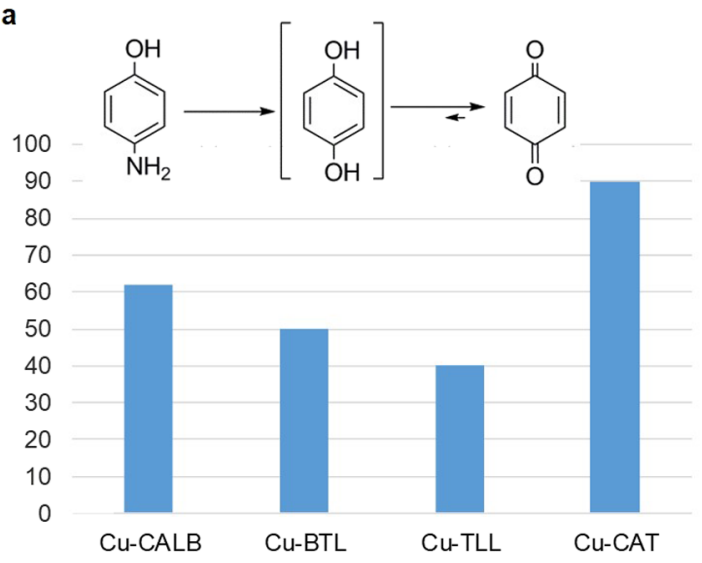

b

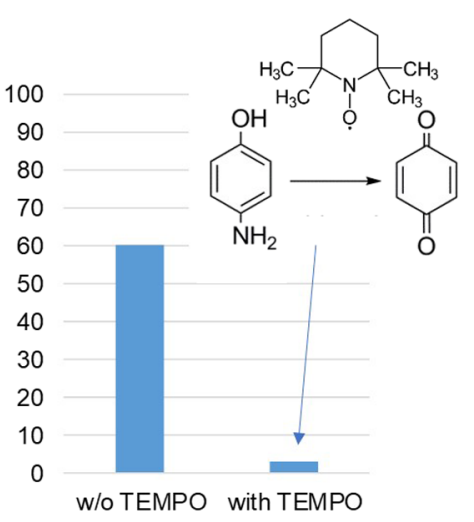

Figure 7. Fenton catalysis in the hydroxylation reaction of $p$-aminophenol to benzoquinone. (a) Conversion of different $\mathrm{Cu}$ hybrids after 8 min reaction. Conditions: $100 \mathrm{mg} / \mathrm{L}$ of $p A P$ in $10 \mathrm{~mL}$ of distilled water, $1 \%, \mathrm{v} / \mathrm{v} \mathrm{H}_{2} \mathrm{O}_{2}$, and $3 \mathrm{mg}$ of $\mathrm{Cu}$ hybrid at room temperature. (b) Reaction catalyzed by Cu-CALB with or without TEMPO. 


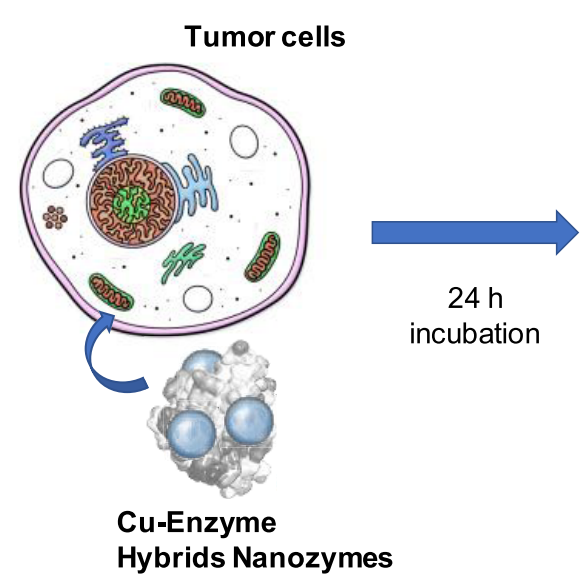

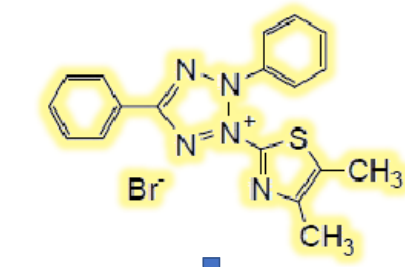

MTT

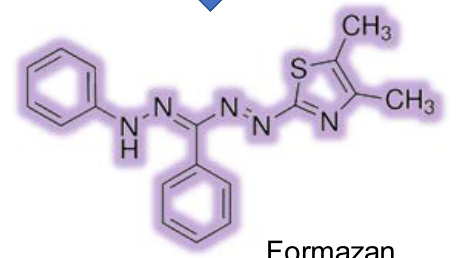

Cytotoxicityassay

Toxic

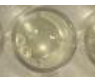

Non-toxic

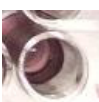

Figure 8. Schematic of the MTT assay.

A
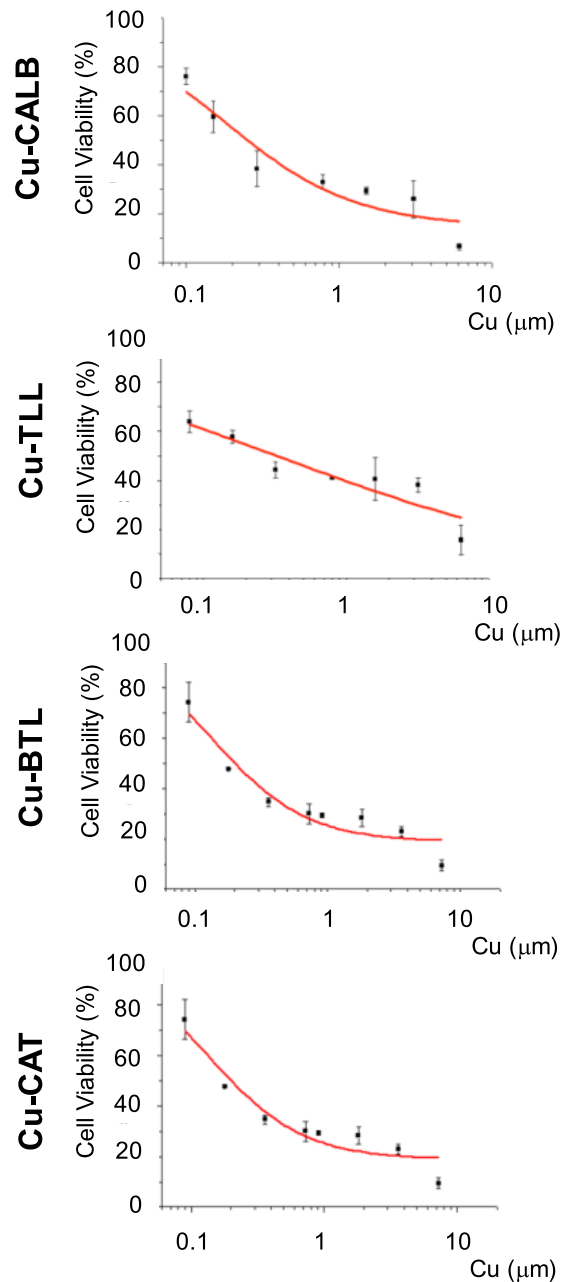

B
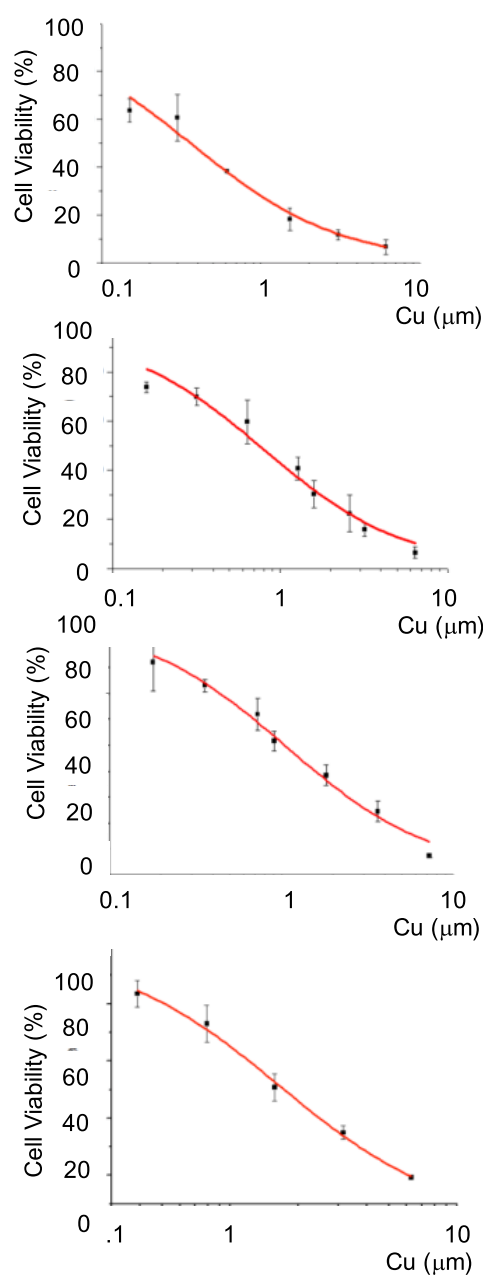

Figure 9. Curve cell viability in cancer cells calculated in $\mu \mathrm{M}$ concentration of $\mathrm{Cu}$ of $\mathrm{Cu}$ hybrids: (A) HeLa cells and (B) HT29 cells.

cells. Cu-CAT exhibited the highest LC50 values in HeLa and HT29 (1.25 and $1.65 \mu \mathrm{M}$ of $\mathrm{Cu}$, respectively) (Table 1). CuTLL $(0.33$ and $0.8 \mu \mathrm{M}$ of $\mathrm{Cu})$ is in between the highest and lowest values. The different enzymes used for preparing the hybrid were tested, and no cytotoxicity was found (Figure S9).
Thus, Cu-CALB hybrid, which presents the smallest size in $\mathrm{Cu}$ nanoparticles, seemed to be the enzyme-like derivative with the highest cytotoxic activity in the tested cell cultures. It has been reported that $\mathrm{Cu}$ can generate reactive oxygen species (ROS) in the cell and ROS increment causes DNA 
Table 1. LC50 ( $\mu \mathrm{M})$ Values of the Different $\mathrm{Cu}$-Enzyme Hybrids on HeLa and HT29 Cell Lines

$\begin{array}{ccc}\text { Cu-enzyme hybrid } & \text { HeLa LC50 Cu }(\mu \mathrm{M}) & \text { HT29 LC50 Cu }(\mu \mathrm{M}) \\ \text { Cu-CALB } & 0.18 & 0.37 \\ \text { Cu-BTL } & 0.13 & 1.05 \\ \text { Cu-TLL } & 0.33 & 0.8 \\ \text { Cu-CAT } & 1.25 & 1.65\end{array}$

damage. ${ }^{47,48}$ According to the results of this work, our $\mathrm{Cu}-$ enzyme hybrids exhibited antitumor properties, as other $\mathrm{Cu}$ compounds previously described in the literature probably based on the oxidative enzyme-mimicking capacity (such as xanthine oxidase- or monoamine oxidases-like activity) of the $\mathrm{Cu}$ nanoparticles on them.

\subsection{Protein Structural Effect of Enzymes as a Scaffold} in the Formation of Enzyme/CuNP Hybrids. The use of an enzyme in the nanozyme synthesis has a key role in the stabilization and formation of homogenously distributed copper nanoparticles and their stabilization on the protein network.

Indeed, the formation of hybrid copper nanoparticles first undergoes by a rapid coordination between particular amino acid residues of the enzyme with the copper ions, generating enzyme-Cu(II) intermediates (Figure 1). It is well described that copper ions have very good coordination capacity, especially with carboxylic groups (Asp, Glu) and also with amino groups, mainly those containing histidine residues. Interaction with cysteine residues may also be possible.

However, the three-dimensional environmental area around these coordinated groups, which can be different depending on the enzyme, seems to play a critical role. In this case, we have seen that employing different enzymes, the same $\mathrm{Cu}$ species were formed.

Therefore, bioinformatic analyses were performed to evaluate the structural environmental effect of the enzymes on the enzyme-like activity of the CuNP sites in different hybrids (Figures 10, S10, and S11).

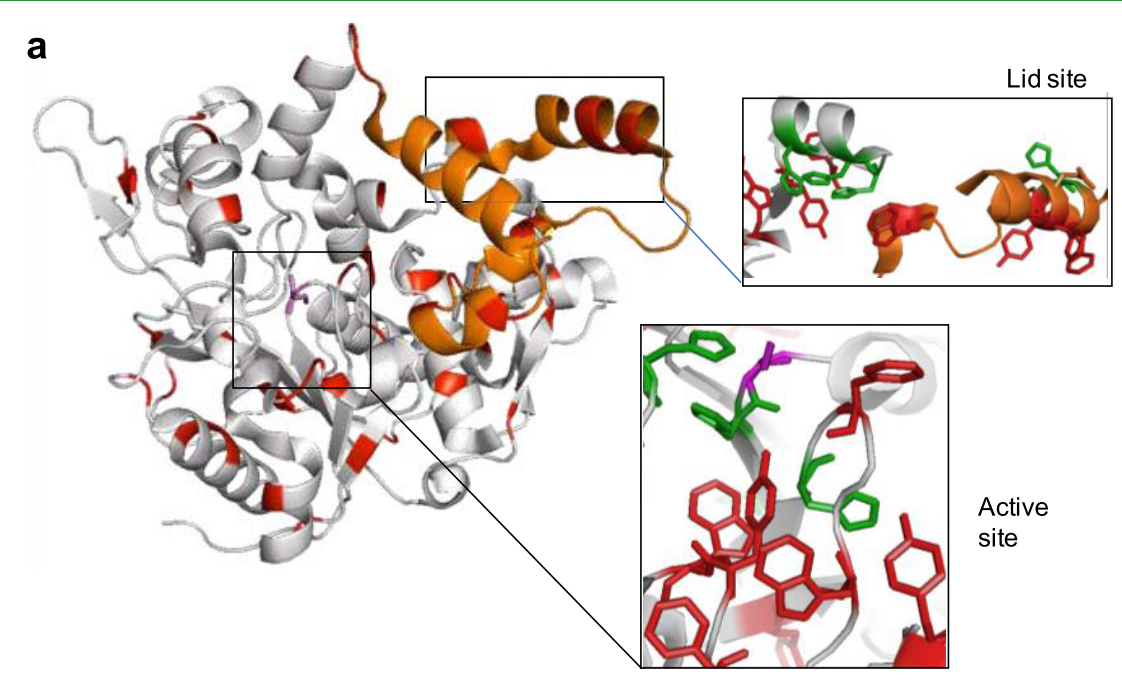

b

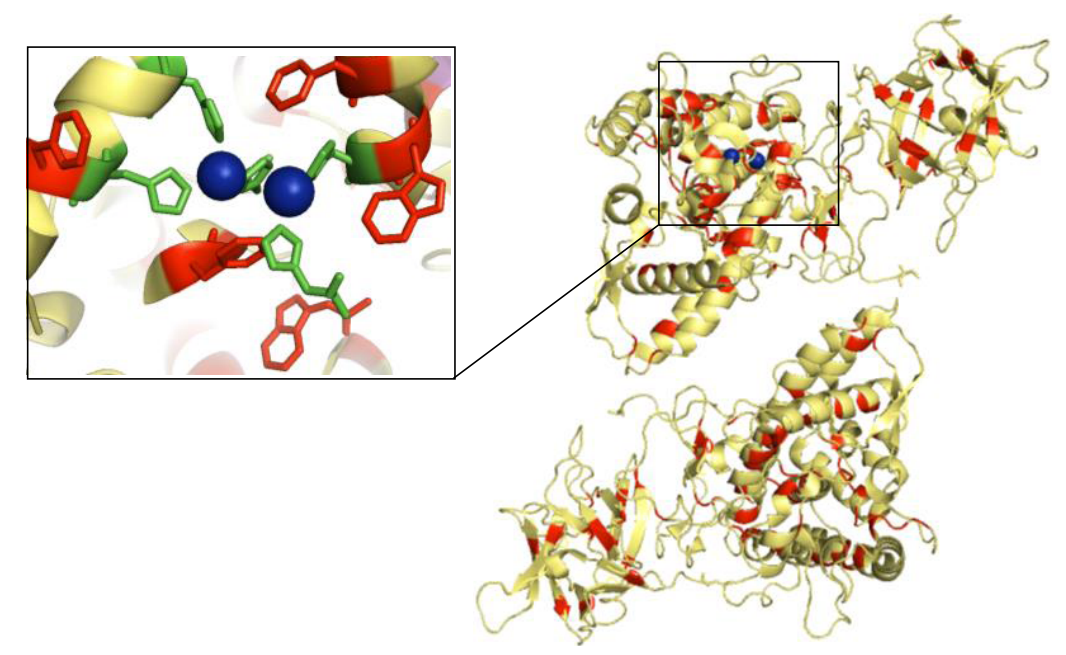

Figure 10. Crystal structure of $B$. thermocatenulatus lipase and mushroom tyrosinase. (a) Cartoon of the crystallized B. thermocatenulatus lipase (BTL) with aromatic amino acids (Trp, Tyr, Phe) in red, histidine residues in green, the catalytic serine in magenta, and the oligopeptide lids in orange. (b) Cartoon of crystallized mushroom tyrosinase (TYR) with aromatic amino acids (Trp, Tyr, Phe) in red, histidine residues in green, and $\mathrm{Cu}$ atoms in blue. The protein structures were obtained from the Protein Data Bank (PDB code: 2W22 (BTL) and 2Y9W TYR), and the picture was created using Pymol v.0.99. 
In particular, in the case of catechol-like activity, $\mathrm{Cu}$ hybrid synthesized using BTL showed the highest enzymatic activity in all cases, being also affected by the $\mathrm{pH}$, especially using LDOPA (Figure 4).

This is a specific lipase, which presents an extremely hydrophobic area surrounding the active site, where also is located an area containing His residues (imidazole groups), where $\mathrm{Cu}$ can be coordinated (Figure 10a). Metal-binding sites in proteins are commonly formed from loops because these regions are reasonably tolerant to sequence modifications outside of coordinating residues.

Furthermore, this lipase presents another interesting area, near one of the two lids involved in the catalytic mechanism of the enzyme, ${ }^{49}$ where we can find a perfect trihistidine pocket (Figure 10a) similar to that present in the natural tyrosinase (Figure 10b). ${ }^{44}$ Both His pockets are surrounded by different aromatic amino acid residues (e.g., Trp, Phe, or Tyr), which are important in the substrate stabilizing the catechol group near the $\mathrm{Cu}$ binding position on the protein for permitting the catalytic transformation, as occurred in the natural enzymes. It has been demonstrated that lipase mechanism has a strong influence on $\mathrm{pH}$, especially the thermoalkalophilic one, ${ }^{49}$ so results showing loss of catechol-like activity in acidic $\mathrm{pH}$ or a different effect using DOPAME as a substrate clearly demonstrate that the typical structural form of this lipase has an influence on the final CuNP site catalysis.

The Enzyme/CuNP hybrids synthesized using catalase involved the use of a multimeric enzyme, with four identical subunits of $80 \mathrm{kDa}$. Each subunit presents 20 histidine residues, for the successful coordination of $\mathrm{Cu}$ ions and a large number of aromatic amino acid residues (Figure S10). This could indicate, although unfortunately the structure of catalase from $A$. niger is still not solved, that structural environment (similar to the BTL case) could be involved in the final good activity of CuNP sites.

An opposite result was obtained with TLL, and even no catechol activity was found under some condition. This lipase has a huge trend to form aggregates-even of eight molecules-that make it, in aqueous solution, a complex enzyme. ${ }^{41}$ This could be the reason why TLL produced larger nanoparticles compared with CALB and lipase with the same molecular weight in monomeric form ${ }^{50}$ (Figure S11). This property has an influence on the natural activity of the enzyme and clearly is also a limitation for the catechol-like activity.

3.9. Stability of the Enzyme/CuNP Nanozymes. Another important property of enzymes is stability. In particular, tyrosinase has been detected as not so stable under biological conditions. In this point, the stability of the most active $\mathrm{Cu}$ hybrids, in comparison to TYR, was evaluated at different temperatures and in the presence of a co-solvent (Figure 11). TYR was rapidly inactivated at $37{ }^{\circ} \mathrm{C}$, and conserving only $38 \%$ of the initial activity after $1 \mathrm{~h}$ incubation, using DOPA as a substrate (Figure 11a). However, the stability of TYR was better using DOPAME as a substrate, conserving more than $50 \%$ activity after $1 \mathrm{~h}$ incubation at $37^{\circ} \mathrm{C}$ (Figure $11 \mathrm{~b})$. The stability of this enzyme in the presence of $40 \%(\mathrm{v} / \mathrm{v})$ acetonitrile at room temperature was also low, conserving around $45 \%$ initial activity value after $1 \mathrm{~h}$ incubation.

The combination of both elements, temperature and cosolvent, caused a complete inactivation of the enzyme after $1 \mathrm{~h}$ incubation (Figure 11).

The different $\mathrm{Cu}$ hybrids synthesized conserved $100 \%$ of their catechol-like activity after $1 \mathrm{~h}$ incubation under any of a

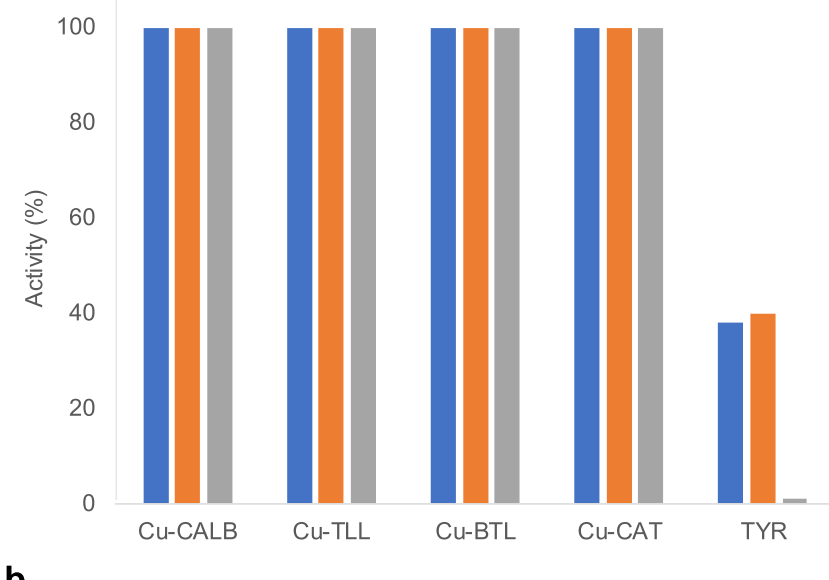

b

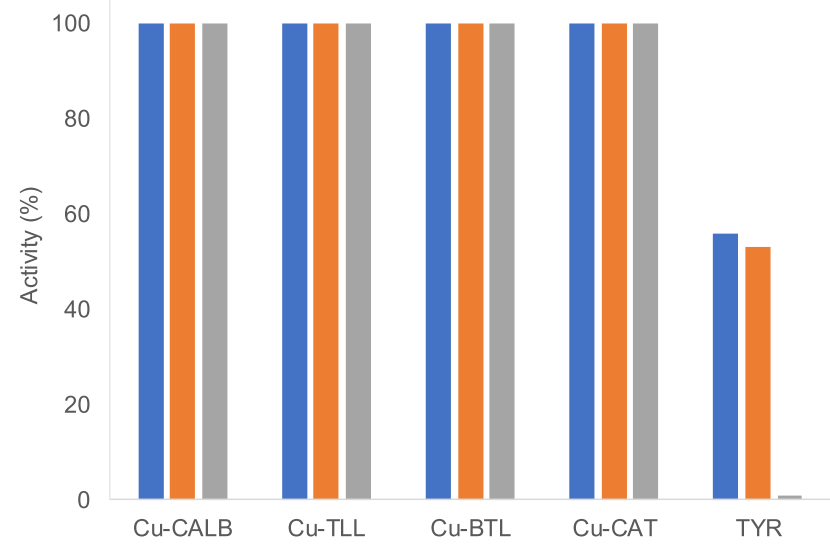

Figure 11. Stability of different Enzyme/CuNP hybrids vs tyrosinase (TYR) in catechol-like activity. (a) Oxidation reaction of L-DOPA. (b) Oxidation reaction of L-DOPAME. Experiments were performed at $37^{\circ} \mathrm{C}$ (blue column), $40 \%(\mathrm{v} / \mathrm{v}$ ) acetonitrile (orange column), and $37^{\circ} \mathrm{C}$ and $40 \%(\mathrm{v} / \mathrm{v})$ acetonitrile (gray column).

these conditions (Figure 11), demonstrating that these nanozymes could represent an alternative to sensitive enzymes in many processes. These enzymes used as a scaffold were stable under these experimental conditions (data not shown), which could be important in terms of maintaining the threedimensional structure, which was also observed in the circular dichroism and fluorescence experiments (Figure 3).

In terms of stability, one of the disadvantages of enzymes is the possible inhibition by substrates. In particular, mushroom tyrosinase (TYR) activity has been demonstrated to be inhibited by different conjugated or aromatic compounds. Here, four of these known substrates ${ }^{51}$ (L-ascorbic acid, transcinnamaldehyde, benzaldehyde, or 4-methoxy benzaldehyde) have been added in the catechol assay and the activity of the $\mathrm{Cu}$ hybrids has been measured (Figure 12).

TYR activity was rapidly inhibited in the presence of these substrates, only conserving some activity $(25 \%$ of initial activity) against trans-cinnamaldehyde and 4-methoxybenzaldehyde (Figure 12).

However, enzyme/CuNP hybrids did not suffer any inhibition; indeed, in some cases, hyperactivation was observed in the presence of these molecules (Figure 12). Very surprising could be the increase of catechol-like activity of hybrids synthesized using CALB and especially using TLL. In particular, $\mathrm{Cu}$ hybrids containing TLL improved its previous catechol activity 72 -fold in the presence of ascorbic acid, while 


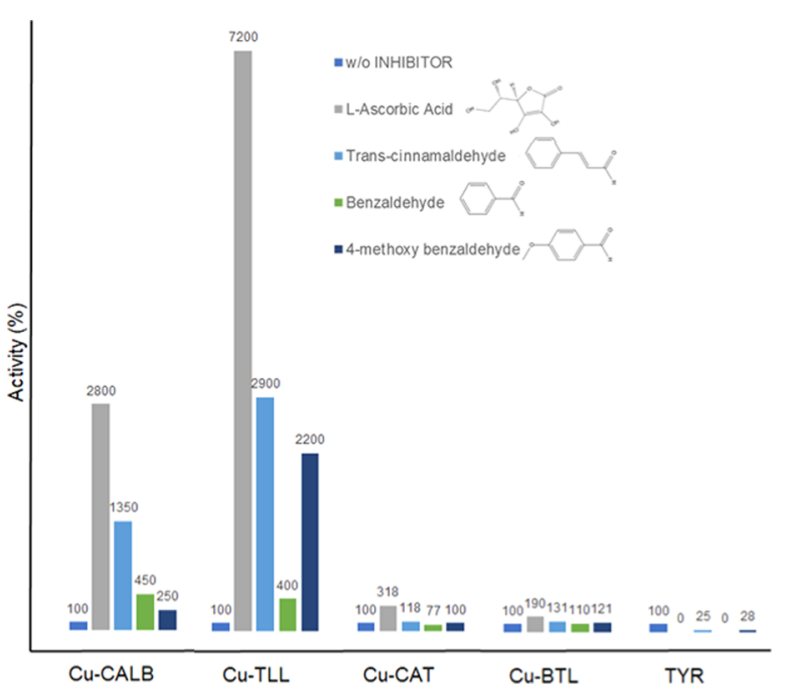

Figure 12. Tyrosinase activity of different Enzyme/CuNP hybrids vs TYR in the presence of different tyrosinase inhibitors. L-DOPA in distilled water assay was used. Condition: $1 \mathrm{mM}$ L-DOPA in $2 \mathrm{~mL}$ of distilled water at rt. The inhibitors were added at $1 \mathrm{mM}$.

the hybrid with CALB showed a 28 -fold improvement (Figure 12). However, this effect could be explained considering the reported increase in hydrolytic activity of CALB in the presence of aromatic or conjugated compounds ${ }^{52}$ or in the case of TLL, whose activity was increased more than 600 times in the presence of a small amount of CTAB (cationic detergent). ${ }^{53}$ Therefore, these results seem to show that the protein structure has an important influence changing the catalytic capacity of the $\mathrm{Cu}$ active sites on it.

\section{CONCLUSIONS}

Enzyme/CuNP hybrids with controlled nanoparticle sizes and environment have been successfully synthesized using different enzymes. The difference between enzymes, where we can use three different lipases with a particular catalytic mechanism, and the use of a supramolecular tetrameric catalase demonstrates the important effect of the structure on the final catalytic properties as nanozymes.

In particular, the oxidase-like catalytic activity of these copper nanozymes was rationally modulated by the enzyme used as a scaffold with important ability to mimic a unique enzyme activity.

For example, the tyrosinase-like activity of these $\mathrm{Cu}$ hybrids was clearly modulate by the enzymes, and Cu-BTL was the one showing very high activity against L-DOPA or L-DOPAME oxidation, demonstrating the role of the enzyme used. Importantly, this nanozyme showed extremely high stability under conditions where natural tyrosinase was completely inactive.

In the catalase-like activity, a synergic activity between the Novozymes catalase and CuNPs created on using this enzyme (Cu-CAT-NL) allows us to achieve a nanozyme with enhanced activity with respect to the natural biocatalyst, with the preservation of the three-dimensional structure of the enzyme as a scaffold being quite critical, which is not observed when lyophilization step was used in the $\mathrm{Cu}$ hybrid creation (Cu-CAT).

Furthermore, a very interesting dual activity was found to increase the catechol-like activity of the CuNPs in Cu-CATNL. In this case, the presence of hydrogen peroxide in the L-
DOPA assay allowed us to greatly improve this activity for the CuNPs by the enzymatic activity in the hybrid (CAT), which generates in situ oxygen in the process. This could be interesting for the design of an L-DOPA biosensor for the detection of tyrosinase, which has been found at elevated amounts on melanoma cancer cells.

For the generation of radical hydroxyl species, Fenton catalyst application of the hybrids demonstrated a clear tendency in lipases as the scaffold used, where the best result was found when smaller nanoparticles were obtained. In this reaction, $\mathrm{Cu}$-CAT was however the most reactive one.

This typical nanozyme activity was evaluated in the cytotoxicity of these hybrids in different human cancer cell lines, and Cu-CALB - which presents the smallest enzyme with the smallest nanoparticle sizes-showed the best antitumor activity.

Therefore, these results showed that different nanozymes of the same $\mathrm{Cu}$ species with a tailor-made enzyme-like activity could have potential therapeutic and diagnostic applications.

\section{ASSOCIATED CONTENT}

\section{Supporting Information}

The Supporting Information is available free of charge at https://pubs.acs.org/doi/10.1021/acsami.0c20501.

TEM figures, XRD pattern, SEM figures, enzymatic-like activity results, MTT assay, protein sequences data, and ICP analysis results (PDF)

\section{AUTHOR INFORMATION}

\section{Corresponding Author}

Jose M. Palomo - Department of Biocatalysis, Institute of Catalysis (CSIC), 28049 Madrid, Spain; 이잉.org/00000002-6464-1216; Email: josempalomo@icp.csic.es

\section{Authors}

Noelia Losada-Garcia - Department of Biocatalysis, Institute of Catalysis (CSIC), 28049 Madrid, Spain

Ana Jimenez-Alesanco - Instituto de Biocomputación y Física de Sistemas Complejos, Joint Units IQFR-CSIC-BIFI, and GBsC-CSIC-BIFI, Universidad de Zaragoza, 50009 Zaragoza, Spain

Adrian Velazquez-Campoy - Fundación ARAID, Gobierno de Aragón, 50018 Zaragoza, Spain; Instituto de Biocomputación y Física de Sistemas Complejos, Joint Units IQFR-CSIC-BIFI, and GBsC-CSIC-BIFI, Universidad de Zaragoza, 50009 Zaragoza, Spain; Fundación Instituto de Investigación Sanitaria de Aragón (IIS Aragón), 50009 Zaragoza, Spain; Centro de Investigación Biomédica en Red en el Área Temática de Enfermedades Hepáticas y Digestivas (CIBERehd), 28029 Madrid, Spain; Departamento de Bioquímica y Biología Molecular y Celular, Universidad de Zaragoza, 50009 Zaragoza, Spain

Olga Abian - Instituto de Biocomputación y Física de Sistemas Complejos, Joint Units IQFR-CSIC-BIFI, and GBsC-CSICBIFI, Universidad de Zaragoza, 50009 Zaragoza, Spain; Fundación Instituto de Investigación Sanitaria de Aragón (IIS Aragón), 50009 Zaragoza, Spain; Centro de Investigación Biomédica en Red en el Área Temática de Enfermedades Hepáticas y Digestivas (CIBERehd), 28029 Madrid, Spain; Departamento de Bioquímica y Biología Molecular y Celular, Universidad de Zaragoza, 50009 


\section{Zaragoza, Spain}

Complete contact information is available at: https://pubs.acs.org/10.1021/acsami.0c20501

\section{Notes}

The authors declare no competing financial interest.

\section{ACKNOWLEDGMENTS}

This work was supported by the Spanish Government and the Spanish National Research Council (CSIC) (projects PIE 201880E011 and 201980E081), Fondo de Investigaciones Sanitarias from Instituto de Salud Carlos III, and European Union (ERDF/ESF, "Investing in your future") (PI15/00663 and PI18/00349 to O.A.), as well as Spanish Ministry of Economy and Competitiveness (BFU2016-78232-P to A.V.C.), Diputación General de Aragón (Predoctoral Research Contract 2019 to A.J.-A., "Protein Targets and Bioactive Compounds Group” E45_20R to A.V.-C., "Digestive Pathology Group” B25_20R to O.A.), and Centro de Investigación Biomédica en Red en Enfermedades Hepáticas y Digestivas (CIBERehd). The authors thank Dr. de las Rivas for the preparation of the BTL enzyme and Dr. Martinez from Novozymes for the gift of CALB, TLL, and CAT enzymes.

\section{REFERENCES}

(1) Dong, H.; Fan, Y.; Zhang, W.; Gu, N.; Zhang, Y. Catalytic mechanisms of nanozymes and their applications in biomedicine. Bioconjugate Chem. 2019, 30, 1273-1296.

(2) Singh, S. Nanomaterials Exhibiting Enzyme-Like Properties (Nanozymes): Current Advances and Future Perspectives. Front Chem. 2019, 7, No. 46.

(3) Jiang, D.; Ni, D.; Rosenkrans, Z. T.; Huang, P.; Yan, X.; Cai, W. Nanozyme: new horizons for responsive biomedical applications. Chem. Soc. Rev. 2019, 48, 3683-3704.

(4) Song, W.; Zhao, B.; Wang, C.; Ozaki, Y.; Lu, X. Functional nanomaterials with unique enzyme-like characteristics for sensing applications. J. Mater. Chem. B 2019, 7, 850-875.

(5) Vong, K.; Eda, S.; Kadota, Y.; Nasibullin, I.; Wakatake, T.; Yokoshima, S.; Shirasu, K.; Tanaka, K. An artificial metalloenzyme biosensor can detect ethylene gas in fruits and Arabidopsis leaves. Nat. Commun. 2019, 10, No. 5746.

(6) Qiu, H.; Pu, F.; Ran, X.; Liu, C. Q.; Ren, J. S.; Qu, X. G. Nanozyme as artificial receptor with multiple readouts for pattern recognition. Anal. Chem. 2018, 90, 11775-11779.

(7) Tian, L.; Qi, J. X.; Oderinde, O.; Yao, C.; Song, W.; Wang, Y. H. Planar intercalated copper (II) complex molecule as small molecule enzyme mimic combined with $\mathrm{Fe}_{3} \mathrm{O}_{4}$ nanozyme for bienzyme synergistic catalysis applied to the microRNA biosensor. Biosens. Bioelectron. 2018, 110, 110-117.

(8) Popov, A. L.; Popova, N. R.; Tarakina, N. V.; Ivanova, O. S.; Ermakov, A. M.; Ivanov, V. K.; Sukhorukov, G. B. Intracellular delivery of antioxidant $\mathrm{CeO}_{2}$ nanoparticles via polyelectrolyte microcapsules. ACS Biomater. Sci. Eng. 2018, 4, 2453-2462.

(9) Yang, B. W.; Chen, Y.; Shi, J. L. Nanozymes in catalytic cancer theranostics. Prog. Biochem. Biophys. 2018, 45, 237-255.

(10) Wang, Z.; Jia, T.; Sun, Q.; Kuang, Y.; Liu, B.; Xu, M.; Zhu, H.; $\mathrm{He}, \mathrm{F} . ; \mathrm{Ga}$, S.; Yang, P. Construction of $\mathrm{Bi} /$ phthalocyanine manganese nanocomposite for trimodal imaging directed photodynamic and photothermal therapy mediated by $808 \mathrm{~nm}$ light. Biomaterials 2020, 228, No. 119569.

(11) Dong, S.; Dong, Y.; Jia, T.; Liu, S.; Liu, J.; Yang, D.; He, F.; Gai, S.; Yang, P.; Lin, Y. GSH-Depleted Nanozymes with HyperthermiaEnhanced Dual Enzyme-Mimic Activities for Tumor Nanocatalytic Therapy. Adv. Mater. 2020, No. 2002439.

(12) Xu, M.; Yang, G.; Bi, H.; Xu, J.; Feng, L.; Yang, D.; Sun, Q.; Gai, S.; He, F.; Dai, Y.; Zhong, C.; Yang, P. Combination of $\mathrm{CuS}$ and
g-C3N4 QDs on upconversion nanoparticles for targeted photothermal and photodynamic cancer therapy. Chem. Eng. J. 2019, 360, 866-878.

(13) Li, S.; Hou, Y.; Chen, Q.; Zhang, X.; Cao, H.; Huang, Y. Promoting Active Sites in MOF-Derived Homobimetallic Hollow Nanocages as a High-Performance Multifunctional Nanozyme Catalyst for Biosensing and Organic Pollutant Degradation. ACS Appl. Mater. Interfaces 2020, 12, 2581-2590.

(14) Zhao, Y.; Yu Huang, Y.; Wu, J.; Zhan, X.; Xie, Y.; Tang, D.; Cao, H.; Wen Yun, W. Mixed-solvent liquid exfoliated MoS2 NPs as peroxidase mimetics for colorimetric detection of $\mathrm{H} 2 \mathrm{O} 2$ and glucose. RSC Adv. 2018, 8, 7252-7259.

(15) Wu, J. J.; Wang, X. Y.; Wang, Q.; Lou, Z. P.; Li, S. R.; Zhu, Y. Y.; Qin, L.; Wei, H. Nanomaterials with enzyme-like characteristics (nanozymes): next-generation artificial enzymes (II). Chem. Soc. Rev. 2019, 48, 1004-1076.

(16) Zhou, Y. B.; Liu, B. W.; Yang, R. H.; Liu, J. W. Filling in the gaps between nanozymes and enzymes: challenges and opportunities. Bioconjugate Chem. 2017, 28, 2903-2909.

(17) Wei, H.; Wang, E. K. Nanomaterials with enzyme-like characteristics (nanozymes): next-generation artificial enzymes. Chem. Soc. Rev. 2013, 42, 6060-6093.

(18) Wang, X. Y.; Hu, Y. H.; Wei, H. Nanozymes in bionanotechnology: from sensing to therapeutics and beyond. Inorg. Chem. Front. 2016, 3, 41-60.

(19) Liu, B.; Liu, J. Surface modification of nanozymes. Nano Res. 2017, 10, 1125-1148.

(20) Huo, M.; Wang, L.; Zhang, H.; Zhang, L.; Chen, Y.; Shi, J. Construction of Single-Iron-Atom Nanocatalysts for Highly Efficient Catalytic Antibiotics. Small 2019, 15, No. 1901834.

(21) Zhao, L.; Cai, J.; Li, Y.; Wei, J.; Duan, C. A host-guest approach to combining enzymatic and artificial catalysis for catalyzing biomimetic monooxygenation. Nat. Commun. 2020, 11, No. 6358.

(22) Zhang, W.; Dynes, J. J.; Hu, Y.; Jiang, P.; Ma, S. Porous metalmetalloporphyrin gel as catalytic binding pocket for highly efficient synergistic catalysis. Nat. Commun. 2019, 10, No. 1913.

(23) Song, Y.; Feng, X.; Chen, J. S.; Brzezinski, C.; Xu, Z.; Lin, W. Multistep Engineering of Synergistic Catalysts in a Metal-Organic Framework for Tandem C-O Bond Cleavage. J. Am. Chem. Soc. 2020, 142, 4872-4882.

(24) Rosenzweig, A. C.; Sazinsky, M. H. Structural insights into dioxygen-activating copper enzymes. Curr. Opin. Struct. Biol. 2006, 16, $729-735$.

(25) Solomon, E. I.; Heppner, D. E.; Johnston, E. M.; Ginsbach, J. W.; Cirera, J.; Qayyum, M.; Kieber-Emmons, M. T.; Kjaergaard, C. H.; Hadt, R. G.; Tian, L. Copper active sites in biology. Chem. Rev. 2014, 114, 3659-3853.

(26) Vaaje-Kolstad, G.; Westereng, B.; Horn, S. J.; Liu, Z.; Zhai, H.; Sorlie, M.; Eijsink, V. G. H. An oxidative enzyme boosting the enzymatic conversion of recalcitrant polysaccharides. Science 2010, $330,219-222$.

(27) Quinlan, R. J.; Sweeney, M. D.; Leggio, L. L.; Otten, H.; Poulsen, J.-C. N.; Johansen, K. S.; Krogh, K. B. R. M.; Jorgensen, C. I.; Tovborg, M.; Anthonsen, A.; Tryfona, T.; Walter, C. P.; Dupree, P.; $\mathrm{Xu}$, F.; Davies, G. J.; Walton, P. H. Insights into the oxidative degradation of cellulose by a copper metalloenzyme that exploits biomass components. Proc. Natl. Acad. Sci. U.S.A. 2011, 108, 1507915084.

(28) Couto, S. R.; Herrera, J. L. T. Industrial and biotechnological applications of laccases: a review. Biotechnol. Adv. 2006, 24, 500-513.

(29) Bergqvist, C.; Ezzedine, K. Vitiligo: A Review. Dermatology 2020, 571-592.

(30) Halaban, R.; Svedine, S.; Cheng, E.; Smicun, Y.; Aron, R.; Hebert, D. N. Endoplasmic reticulum retention is a common defect associated with tyrosinase-negative albinism. Proc. Natl. Acad. Sci. U.S.A. 2000, 97, 5889-5894.

(31) Baldo, B. A. Enzymes approved for human therapy: indications, mechanisms and adverse effects. BioDrugs 2015, 29, 31-55. 
(32) Vellard, M. The enzyme as drug: application of enzymes as pharmaceuticals. Curr. Opin. Biotechnol. 2003, 14, 444-450.

(33) Craik, C. S.; Page, M. J.; Madison, E. L. Proteases as therapeutics. Biochem. J. 2011, 435, 1-16.

(34) Zhang, Q.; Chen, S.; Wang, H.; Yu, H. Exquisite enzymeFenton biomimetic catalysts for hydroxyl radical production by mimicking an enzyme cascade. ACS Appl. Mater. Interfaces 2018, 10, 8666-8675.

(35) Li, M.; Zhang, H.; Hou, Y.; Wang, X.; Xue, C.; Li, W.; Cai, K.; Zhao, Y.; Luo, Z. State-of-the-art iron-based nanozymes for biocatalytic tumor therapy. Nanoscale Horiz. 2020, 5, 202-217.

(36) Wang, R.; Yan, C.; Zhang, H.; Guo, Z.; Zhu, W. H. In vivo realtime tracking of tumor-specific biocatalysis in cascade nanotheranostics enables synergistic cancer treatment. Chem. Sci. 2020, 11, 3371-3377.

(37) Romero, O.; Filice, M.; de las Rivas, B.; Carrasco-Lopez, C.; Klett, J.; Morreale, A.; Hermoso, J. A.; Guisan, J. M.; Abian, O.; Palomo, J. M. Semisynthetic Peptide-Lipase Conjugates for Improved Biotransformations. Chem. Commun. 2012, 48, 9053-9055.

(38) Lopez-Tejedor, D.; Palomo, J. M. Efficient purification of a highly active $\mathrm{H}$-subunit of tyrosinase from Agaricus bisporus. Protein Expression Purif. 2018, 145, 64-70.

(39) Xie, W.-Y.; Song, F.; Wang, X.-L.; Wang, Y.-Z. Development of Copper Phosphate Nanoflowers on Soy Protein toward a Superhydrophobic and Self-Cleaning Film. ACS Sustainable Chem. Eng. 2017, 5, 869-875.

(40) Tan, X.; Wang, X.; Zhang, L.; Liu, L.; Zheng, G.; Li, H.; Zhou, F. Stable and Photothermally Efficient Antibody-Covered Cu3(PO4)2@Polydopamine Nanocomposites for Sensitive and Cost-Effective Immunoassays. Anal. Chem. 2019, 91, 8274-8279.

(41) Lawson, D. M.; Brzozowski, A. M.; Rety, S.; Verma, C.; Dodson, G. G. Probing the nature of substrate binding in Humicola lanuginosa lipase through $\mathrm{X}$-ray crystallography and intuitive modelling. Protein Eng., Des. Sel. 1994, 7, 543-550.

(42) Durgadas, C. V.; Sharma, C. P.; Sreenivasan, K. Fluorescent gold clusters as nanosensors for copper ions in live cells. Analyst 2011, 136, 933-940.

(43) Sicchieri, L. B.; Moreira Monteiro, A.; Samad, R. E.; Ito, A. S.; Figueiredo Neto, A. M.; Dias Vieira, N.; Gidlund, M.; Coronato Courrol, L. Study of tryptophan lifetime fluorescence following lowdensity lipoprotein modification. Appl. Spectrosc. 2013, 67, 379-384.

(44) Ismaya, W.; Rozeboom, H. J.; Weijn, A.; Mes, J. J.; Fusetti, F.; Wichers, H. J.; Dijkstra, B. W. Crystal Structure of Agaricus bisporus Mushroom Tyrosinase: Identity of the Tetramer Subunits and Interaction with Tropolone. Biochemistry 2011, 50, 5477-5486.

(45) Thawari, A. G.; Rao, C. P. Peroxidase-like catalytic activity of copper-mediated protein-inorganic hybrid nanoflowers and nanofibers of $\beta$-lactoglobulin and $\alpha$-lactalbumin: synthesis, spectral characterization, microscopic features, and catalytic activity. ACS Appl. Mater. Interfaces 2016, 8, 10392-10402.

(46) Lale, S. V.; Goyal, M.; Bansal, A. K. Development of lyophilization cycle and effect of excipients on the stability of catalase during lyophilization. Int. J. Pharm. Invest. 2011, 1, 214-221.

(47) Sarbadhikary, P.; Dube, A. Iodinated chlorin p6 copper complex induces anti-proliferative effect in oral cancer cells through elevation of intracellular reactive oxygen species. Chem.-Biol. Interact. 2017, 277, 137-144.

(48) Mizutani, H.; Nishimoto, A.; Hotta, S.; Ikemura, K.; Imai, M.; Miyazawa, D.; Ohta, K.; Ikeda, Y.; Maeda, T.; Yoshikawa, M.; Hiraku, Y.; Kawanishi, S. Oxidative DNA Damage Induced by Pirarubicin, an Anthracycline Anticancer Agent, in the Presence of Copper (II). Anticancer Res. 2018, 38, 2643-2648.

(49) Carrasco-López, C.; Godoy, C.; de las Rivas, B.; FernándezLorente, G.; Palomo, J. M.; Guisán, J. M.; Fernández-Lafuente, R.; Martínez-Ripoll, M.; Hermoso, J. A. Activation of bacterial thermoalkalophilic lipases is spurred by dramatic structural rearrangements. J. Biol. Chem. 2009, 284, 4365-4372.

(50) Uppenberg, J.; Hansen, M. T.; Patkar, S.; Jones, T. A. The sequence, crystal structure determination and refinement of two crystal forms of lipase B from Candida antarctica. Structure 1994, 2, 293-308.

(51) Zolghadri, S.; Bahrami, A.; Khan, M. T. H.; Munoz-Munoz, J.; Garcia-Molina, F.; Garcia-Canovas, F.; Saboury, A. A. A comprehensive review on tyrosinase inhibitors. J. Enzyme Inhib. Med. Chem. 2019, 34, 279-309.

(52) Zisis, T.; Freddolino, P. L.; Turunen, P.; van Teeseling, M. C. F.; Rowan, A. E.; Blank, K. G. Interfacial activation of Candida antarctica lipase B: combined evidence from experiment and simulation. Biochemistry 2015, 54, 5969-5979.

(53) Moreno-Pérez, S.; Ghattas, N.; Filice, M.; Guisan, J. M.; Fernandez-Lorente, G. Dramatic hyperactivation of lipase of Thermomyces lanuginosa by a cationic surfactant: Fixation of the hyperactivated form by adsorption on sulfopropyl-sepharose. J. Mol. Catal. B: Enzym. 2015, 122, 199-203. 